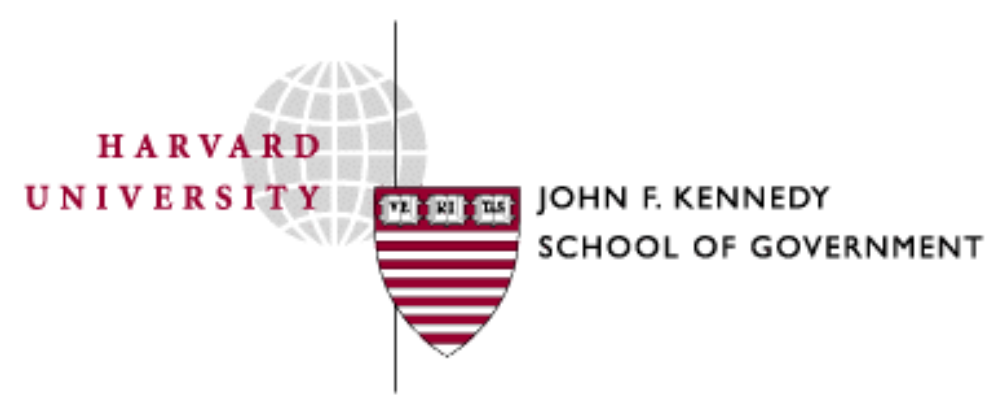

Faculty Research Working Papers Series

\title{
Who Benefits from the Education Saving Incentive? \\ Income, Educational Expectations and the Value of the 529 and Coverdell
}

\author{
Susan Dynarski
}

April 2004

RWP04-019

The views expressed in the KSG Faculty Research Working Paper Series are those of the author(s) and do not necessarily reflect those of the John F. Kennedy School of Government or Harvard University. Copyright belongs to the author(s). Papers may be downloaded for personal use only. 


\title{
Who Benefits from the Education Saving Incentives? Income, Educational Expectations and the Value of the 529 and Coverdell
}

\author{
Susan Dynarski \\ Harvard University, Kennedy School of Government \\ \& National Bureau of Economic Research \\ 79 J.F.K. Street, Cambridge, MA 02138
}

This Version:

April 5, 2004

\begin{abstract}
This paper examines the incentives created by the 529 and Coverdell tax-advantaged savings accounts. I find that the advantages of the 529 and Coverdell rise sharply with income, for three reasons. First, those with the highest marginal tax rates benefit the most from sheltering income, gaining most in both absolute and relative terms. Second, the tax penalties that are assessed on families whose children do not use their Coverdell accounts to pay for college hit some families harder than others. Strikingly, those in the top two tax brackets benefit more from non-educational use of a Coverdell than those in the bottom bracket gain from its educational use. Finally, the college financial aid system reduces aid for those families that have any financial assets, including an ESA or 529. Since the highest-income families are unaffected by this aid tax, this further intensifies the positive correlation between income and the advantages of the taxadvantaged college savings accounts.
\end{abstract}

${ }^{*}$ I gratefully acknowledge support from NBER-National Institute on Aging Grants P30-AG12810 and K12-AG000983. Naomi Calvo, Joe Ciesla, Betsy Kent and Juan Saavedra provided excellent research assistance. I thank Andrew Samwick for helpful comments. 


\section{INTRODUCTION}

In the past few years, a new breed of tax-advantaged savings vehicle has emerged. The federal Coverdell Education Savings Account (ESA) allows annual, after-tax deposits of up to $\$ 2,000$ a year, with asset earnings untaxed so long as withdrawals are used for educational expenses. At the state level, every state but Washington offers a tax-advantaged 529 savings plan. These accounts allow participants to make annual, after-tax deposits of up to $\$ 11,000$ a year per child, comparable to the annual ceilings on the $401(\mathrm{k}) .{ }^{1}$ The tax treatment is like that of the ESA: earnings are untaxed by the federal government, and by almost every state, when the funds are used for postsecondary education. In about half the states, deposits are exempt from state taxation, further increasing the income tax advantages of the 529 .

This paper calculates the incentives created by these new savings vehicles and how they vary by income. I find that the advantages of the 529 and ESA rise sharply with income, for three reasons. First, those with the highest marginal tax rates benefit the most from sheltering income, gaining most in both absolute and relative terms. Second, the accounts are risky for families for whom the college attendance of children is uncertain, since account holders are penalized if the accounts are not used for schooling. The current penalty structure leaves most benefits intact for the upper brackets. Relative to their other investment options, those in the top two tax brackets gain more from non-qualified use of a 529 or Coverdell than those in the bottom bracket gain from qualified use. Third, Finally, the college financial aid system reduces aid for those families that have any financial assets, including an ESA or 529. Since the highest-income families are unaffected by this aid tax, this further intensifies the positive correlation between income and the advantages of the tax-advantaged college savings accounts.

The paper is organized as follows. In the second section, I provide some background on the taxadvantaged college savings plans, as well as evidence from the 2001 Survey of Consumer Finances on the characteristics of those who invest in these accounts. In the third section, I calculate returns on various

\footnotetext{
${ }^{1}$ This is the largest amount that can be deposited in a 529 without triggering a gift tax. I further discuss 529 contribution limits below. Since the 401(k) contribution ceilings are for pre-tax income, and the 529 limits for post-tax income, in effect larger contributions are allowed to the 529 than the $401(\mathrm{k})$.
} 
savings vehicles net of income taxes for a typical household. In the fourth, I examine how the benefit of the education savings accounts varies by income, exploring in turn the impact of marginal tax rates, penalties for non-educational use of the accounts, and the financial aid tax. The fifth section discusses and concludes.

\section{TAX INCENTIVES FOR COLLEGE SAVING: BACKGROUND}

\section{History of the Coverdell Education Savings Accounts}

In 1997, the Education IRA was established and in 2001 renamed the Coverdell Education Savings Account (ESA). The ESA is structured much like the Roth IRA. In both types of vehicles, aftertax dollars grow tax-free. Earnings are never taxed if ESA withdrawals are used for postsecondary expenses or if Roth funds are withdrawn after age $591 / 2$. Annual contributions to the ESA were capped at $\$ 500$ per child until 2001, when the contribution limit was raised to $\$ 2,000$ and educational expenses were expanded to include primary and secondary education.

\section{History of the 529 Savings Plans}

While the ESA is a product of federal legislation, the 529 savings plans are an innovation of the states. The 529 savings plans have their roots in prepaid tuition plans, the first of which was introduced by Michigan in 1986. Those who purchased shares in Michigan's plan were guaranteed that their investment would cover the cost of a certain number of semesters at Michigan schools. Essentially, Michigan created a savings plan whose rate of return was linked to tuition costs at the state's public postsecondary schools, thereby allowing parents to insure against the risk of rising tuition prices. ${ }^{2}$ Michigan exempted investment returns in its prepaid plan from state taxes, and argued to the Internal Revenue Service (IRS) that returns should also be exempted from federal taxes. The IRS disagreed, but Michigan went forward with the plan and sued the IRS for a refund of taxes paid, winning its case in

\footnotetext{
${ }^{2}$ A key drawback of the prepaid plans is that the tuition guarantee is only for in-state schools. Funds can be used at out-of-state schools, but the implied rate of return on funds used in this way is quite low.
} 
1994. While the Michigan case was wending through the courts, several other states introduced their own prepaid tuition plans.

In 1997, Congress codified the federal tax treatment of the tuition plans in Internal Revenue Code Section 529. IRC 529 also contains language that recognized a variant on the prepaid plans that had been introduced by a handful of states: the tax-advantaged college savings plan. Like the ESA, these new savings plans allowed after-tax investments to grow free of federal and state taxes; however, withdrawals used for postsecondary costs were exempt only from state taxation. With the passage of tax reform in 2001, the federal tax on withdrawals from 529 savings plans was eliminated. ${ }^{3}$ States that did not already have a savings plan quickly established one. As of summer 2003, every state except Washington had a 529 savings plan, as does the District of Columbia. The growth of the 529 savings plans has far outstripped that of the prepaid plans, likely because of their greater fungibility and potentially higher returns. In this paper, I focus on the 529 savings plans.

\section{Eligibility for and Tax Advantages of the 529 and ESA}

The tax treatments of the ESA and 529 are quite similar: after-tax dollars put into savings and earnings are not taxed as they accrue, or at withdrawal, if the withdrawal is used for educational expenses. However, there are some key differences between the two savings vehicles.

First, there is an income limit on participation in the ESA. Joint-filer households with adjusted gross income (AGI) above $\$ 220,000$, and single-filer households with AGI above $\$ 110,000$, cannot contribute to an ESA; eligibility begins to phase out at $\$ 190,000$ and $\$ 95,000$, respectively. There is no income limit on contributions to a 529 savings plan. ${ }^{4}$

\footnotetext{
${ }^{3}$ This federal tax treatment of the 529 savings plans sunsets in 2010 . The present analysis assumes that the provision will be extended indefinitely.

${ }^{4}$ No state has an income cap on eligibility for the exclusion of 529 earnings from taxation. Only Georgia has an income cap on eligibility for the deduction of contributions from state taxable income; the income cap is $\$ 100,000$ for joint-filer households.
} 
A second distinguishing characteristic of the 529 is that its contribution limits are much higher than that on the ESA. The annual contribution limit to an ESA is $\$ 2,000$ per child. By contrast, each parent can make an annual deposit of $\$ 11,000$ per child into a 529 without triggering a gift tax. A twoparent family with three children can therefore move $\$ 66,000$ per year into a tax-advantaged 529 account. Grandparents, or any relative, can also make deposits up to these limits, further expanding the assets that can be shielded from taxation. Further, any contributor can elect to make five years' worth of contributions in a single year, as long as none are made over the next four years, thereby allowing each person a contribution of up to $\$ 55,000$ in a single year. Each state has a lifetime limit, periodically adjusted, on contributions that can be made to its 529 plan in the name of a beneficiary. This limit currently averages $\$ 241,000$ and ranges from $\$ 182,000$ in Louisiana to $\$ 305,000$ in South Dakota. ${ }^{5}$

Third, while families can invest their ESAs as they wish, they are constrained in their ability to allocate assets in a 529. Each state determines the investment options open to investors in its plan and, by federal law, assets can be reallocated by the investor only once a year. Until recently, most 529 savings plans provided only a single investment option, an age-based portfolio that grew less aggressive as the child neared college age. Most plans now offer several investment options.

Fourth, the degree to which the account owner can control the use of funds differs between the 529 and ESA. A 529 account owner - generally a parent, but perhaps a grandparent or other relative retains control of the account. At any time, the 529 owner can withdraw the funds, though if they are not used for college expenses she will have to pay a penalty and ordinary income taxes on the earnings portion of the withdrawal. A person that establishes an ESA for a child, by contrast, cannot withdraw the funds, since the ESA is technically owned by the beneficiary. While the adult can change the ESA beneficiary at any time, he or she cannot simply close the account and take back the funds. Should the beneficiary reach age 30 with funds still in the ESA, the funds are distributed to the beneficiary, with ordinary income taxes (at the beneficiary's rate) and a 10 percent penalty assessed on the earnings.

\footnotetext{
${ }^{5}$ Cerulli Associates (2003).
} 
Finally, the 529s are creatures of state government, with each state sponsoring its own plan. Individuals are free to participate in any state's plan. Many of the states encourage their residents to invest in the local plan by allowing them to deduct contributions to its 529 savings plan from state taxable income. Each state contracts with a mutual fund company to run its plan, chooses the mutual funds that will be available to investors, decides upon the treatment of deposits and earnings for the purposes of state taxation, and negotiates fees that will be paid by the investor to the state and fund company. There is, therefore, heterogeneity across the states in 529 characteristics, particularly in portfolio choice and net returns. Variation in net returns is driven not only by the fact that some states allow the deduction of contributions from taxable income, but by differences in state marginal tax rates and the fees charged by the states for 529 accounts. In ongoing work, I examine these sources of cross-state variation in 529 returns and their impact on savings decisions.

Of note, I have found that much of the cross-state variation in net returns on $529 \mathrm{~s}$ is driven by fees, which not only vary considerably across the states but appear higher, on average, than those on retail mutual funds, IRAs or ESAs. In order to focus on variation in returns to the 529 and ESA across income groups, I assume here that pretax returns on the various savings vehicles are identical. However, for those cases in which I find only a small advantage to the 529 , it should be kept in mind that this advantage could be erased by higher fees. Because, as we shall see, the tax advantages of the savings account rise with income, the fees necessary to eliminate these tax advantages also rise with income.

Here, I give a rough sense of the differential in fees necessary to erase the tax advantages of the 529. Consider a family with an income of $\$ 50,000$ trying to decide between putting funds in a 529 or a standard, non-tax-advantaged mutual fund. Assume both savings vehicles have the same gross returns, the family's home state does not allow the deduction of 529 contributions from state taxable income, and that the state's income tax rates are at the national median.

Under this scenario, the 529 will be a worse deal if its fees produce an annualized return that is 70 basis points below the return on the non-advantaged account. For a family with $\$ 335,000$ in income, the relevant difference in annualized returns is 145 basis points. If a state offers a deduction for 529 
contributions, the advantages of the 529 rise and a larger fee difference is needed to make the 529 a worse deal than a non-advantaged account: 180 basis points for the high-income household and 100 points for the middle-income household. ${ }^{6}$

These are large fee differentials, but they are not beyond the range of fees observed in some state 529 plans. In particular, 529s sold through financial advisors generally charge loads, which could easily produce asset losses comparable to those just discussed. In every state 529 , however, there is an option to purchase without an advisor, thereby avoiding these sales charges. Less easily avoided are high, annual asset-based fees in some plans. Wyoming's plan charges annual fees of 1.8 to 2.4 percent of assets. Since retail mutual funds are available that charge asset-based fees below 0.5 percent (e.g., Vanguard's index funds), this is a case in which high fees in a 529 more than erase its tax advantages. Many Wyoming residents would yield higher returns in a non-advantaged account with lower fees. ${ }^{7}$

\section{Profile of the 529 and ESA Investor}

In this section, I present evidence on the type of household that invests in the education savings accounts. Since the 529 has become broadly available only in recent years, data on 529 investors are scarce. The 2001 Survey of Consumer Finances is the first representative survey to gather information on 529 savings plans. However, the 2001 SCF predates the recent expansion of the tax advantages of the 529 and ESA and resulting surge in account volume. At the start of 2001, about twenty states did not even have a 529 savings plan in place, while today every state but Washington has established one. As a result, much of the growth in 529 savings plan accounts occurred after the 2001 SCF was administered. From the end of 2000 to the end of 2002, the number of 529 savings plan accounts grew from half a million to 3.1 million. Over the same period, assets held in these accounts grew from $\$ 3.1$

\footnotetext{
${ }^{6}$ Note that if fees are any higher in a 529 (without a deduction) than they are in a Traditional IRA, the 529 will be a worse deal. This is because, as we shall see, these two vehicles have exactly the same tax advantages, so even small differences in fees will tip the scale toward the IRA.

${ }^{7}$ Wyoming has no income tax, so the tax benefits of the 529 are lower than those in the typical state, making this plan an even worse deal.
} 
billion to $\$ 20$ billion. ${ }^{8}$ The SCF therefore understates the current incidence of investment in $529 \mathrm{~s}$ and ESAs. Further, the portrait of the typical savings plan investor that emerges from the SCF may not accurately reflect the profile of today's typical investor, since the early adopters may differ systematically from later investors.

Summary statistics for the SCF sample are shown in Table $1 .{ }^{9}$ Column (1) shows the statistics for all households with children 16 and under, while Column (2) shows statistics for only those households that hold a 529 or ESA. As of 2001, three percent of households with children report holding an ESA or 529. ${ }^{10}$ Education savers are 41 years old, on average, and their oldest child is nine. They have two children and are well-educated, with over 90 percent having at least 16 years of education. Their median income is $\$ 91,000$ and their median net worth $\$ 281,000$. Among education savers, the mean balance in 529 accounts is $\$ 15,000$ and in IRA or Keogh accounts is $\$ 21,000 .^{11}$

Column (4) shows the difference in characteristics between the college savers and the rest of the population with children; the standard errors of these differences are also shown. The education savers are older, and have younger children. Most notably, their median household income is $\$ 41,000$ above the sample median of $\$ 50,000$. They are also better-educated; just 37 percent of all households with children have a BA or more, as compared to 91 percent of the education savers.

It is not surprising to find that education savers have higher incomes and education than the rest of the population, as in any dataset these characteristics strongly predict a higher incidence and level of saving. A more interesting question is whether those who invest in the 529 and ESA differ from those

\footnotetext{
${ }^{8}$ Cerulli Associates (2003).

${ }^{9}$ The SCF provides multiple imputations, each of which produced statistically identical versions of Table 1. I use imputation two, and also use the sample weights provided.

${ }^{10}$ The SCF is a relatively small survey. Once the sample is limited to households with children under sixteen, there are just fifteen hundred observations. The three percent holding an ESA or 529 translates into fewer than 50 households. These small numbers preclude any fine cuts of the data.

${ }^{11}$ A single question was asked about balances in all forms of IRAs, including Roth IRAs, Traditional IRAs and Education IRAs, the former name for ESAs. As a result, it is not possible to separately calculate holdings in ESAs.
} 
who save in other tax-advantaged vehicles. If the income and education of education savers are lower than those of other savers, this would suggest that the education savings accounts may be attracting those who might not otherwise save at all.

A particularly illuminating comparison is between education savers and those savers who make use of the Roth IRA, Traditional IRA and Keogh. These accounts closely resemble the 529 and ESA: their tax advantages are similar and none of these accounts are employer-provided. This is important because employer-provided accounts, such as the 401(k), ease the saving process: employers automatically set up accounts for employees, choose a mutual fund provider, select a menu of mutual funds, provide payroll deduction, and may match employee contributions. By contrast, investing in the education savings accounts, like investing in the Keogh and IRAs, requires considerable effort and initiative. An investor in a 529 or ESA must actively decide to open an account, research the available options, choose a financial provider, and arrange for deposits.

Column (3) shows the characteristics of the retirement savers, the 38 percent of households with children who invest in an IRA or Keogh. The retirement savers have a median income somewhat lower than that of the education savers $-\$ 75,000$ vs. $\$ 91,000$. The median net worth of the retirement savers is also lower $-\$ 228,000$ vs. $\$ 281,000$. Column (5) shows these differences between the education savers and the retirement savers. Education savers have incomes, education and wealth that are higher than those of both the retirement savers and the general population.

The picture that emerges, then, at least as of 2001, is that those who take up 529 and Coverdell accounts are a relatively elite group. Their characteristics suggest that they are not new savers, but those who already have substantial savings in other vehicles. ${ }^{12}$ This may be true, in part, because of the relative youth of the programs. Those who seek out information about these new instruments - the early adapters - may differ systematically from those who join in when the programs are more well-established. College

\footnotetext{
${ }^{12}$ What we cannot learn from this table is whether the 529/ESA accounts are new dollars saved or dollars shifted from other vehicles. In ongoing work, I attempt to answer this question by making use of crossstate variation in net returns to and timing of the introduction of the 529 savings plans.
} 
savers may become more similar to the typical household with children, and to other savers, as the programs widen in popularity.

\section{CALCULATION OF AFTER-TAX RETURNS ON COVERDELL, 529 AND ALTERNATIVE}

\section{SAVINGS VEHICLES}

In this section, I calculate returns, net of the income tax, on the 529 and ESA, in absolute terms and relative to other vehicles. I first show variation in net returns across vehicles for a single household type, with household income of $\$ 100,000$ and two dependent children. Since the benefits of taxadvantaged accounts vary with marginal tax rates, I then calculate returns for a range of household incomes.

\section{Assumptions}

For the purposes of assigning tax rates, I consider a household that consists of a married couple, with two dependent children, filing jointly, with no itemized deductions. All earned parental income is

assumed to come from one earner. ${ }^{13}$ I assume that the children have enough earned or unearned income to require that they pay taxes on returns to assets held in their name. ${ }^{14}$ The marginal federal and state tax rates on earned income, capital gains, dividends and interest for this household, as well as for the other income groups I will be analyzing, are shown in Table 2 . The state tax rates in Table 2 are the average of

\footnotetext{
${ }^{13}$ Some assumption about the distribution of earned income within the household must be made in order to assign FICA rates. For each earner, the FICA rate is 7.65 percent up to $\$ 87,000$ and 1.45 percent thereafter.

${ }^{14}$ The tax rate on a child's unearned income depends on her income and age. For children with low enough income, the tax rate is zero. For children under 14, income between $\$ 750$ and $\$ 1,500$ is taxed at the child's marginal rate and income above $\$ 1,500$ is taxed at the parent's marginal rate. For children over 14 , all income above $\$ 750$ is taxed at the child's marginal rate. For the purposes of the paper, I assume that the child's income is such that her unearned income is taxed at the child's marginal rate and that the child's tax rate is that of the lowest bracket. See US Department of the Treasury (2003) for rules on the taxation of dependent children.
} 
the states' 2002 marginal tax rates for each income group, as calculated by the National Bureau of Economic Research's TAXSIM program. ${ }^{15}$

Table 2 shows, and the paper's calculations use, federal tax rates effective as of the Jobs and Growth Tax Relief Reconciliation Act (JGTRRA) of 2003. Some of these rates are scheduled to revert to pre-2003 rates in a few years. Since it is difficult to forecast which, if any, of these provisions will be allowed to sunset, in this paper I calculate the effect of making the current tax rates permanent.

For each savings vehicle, I calculate the return to $\$ 1,000$ of pretax income placed in an account at the time of a child's birth. A family saving for college will likely start with a portfolio heavily weighted toward stocks, moving toward a more conservative mix as college nears. Every state's 529 savings plan offers an age-based portfolio that follows this pattern. I use a portfolio mix typical of state $529 \mathrm{~s}$ in calculating returns; this portfolio is shown in Table 3. I assume an identical portfolio mix for the other savings vehicles, so that any the variation in returns across the vehicles will be induced by variation in their treatment by the income tax and aid systems.

Bonds are assumed to earn a nominal rate of four percent. Stocks are assumed to earn a nominal rate of nine percent, with two percent paid as dividends and the balance as long-term capital gains. Capital gains are realized when the funds are withdrawn from the account in order to pay for college; these withdrawals begin at the end of the eighteenth year. ${ }^{16}$ After any relevant taxes on asset earnings are paid, earnings are reinvested.

I calculate returns for the 529, ESA, a non-tax-advantaged mutual fund account in the name of the parent, a Uniform Transfer to Minors Act (UTMA) account in the name of the student, and a Traditional IRA. Table 4 summarizes the income tax treatment of these savings vehicles. In about half the states, deposits to the 529 are excluded from state taxable income. I calculate returns for $529 \mathrm{~s}$ both

\footnotetext{
${ }^{15}$ The average is taken over the states that have an income tax. I use effective marginal state tax rates calculated by TAXSIM, rather than the bracket rates. The effective marginal rates account for the interaction of state and federal taxes as well as the phase-out of various credits and deductions.

${ }^{16}$ The family withdraws $1 / n$th of the remaining balance each year, with $n$ representing the number of years remaining until college completion. For the calculations in the paper, I assume four years of college.
} 
with and without this upfront deduction. Note that the IRA can be used for higher education expenses without the 10 percent penalty usually assessed on withdrawals before retirement age. ${ }^{17}$

\section{Calculation of Returns Net of Income Taxes for the Savings Vehicles}

I first calculate the nominal returns for a family with household income of $\$ 50,000$, using the assumptions laid out above. The return for a non-advantaged mutual fund account, held in the name of the parent, will form the benchmark used to gauge the financial benefits of the other, tax-advantaged vehicles.

After paying Social Security and Medicare taxes (FICA), as well as federal and state income taxes, on $\$ 1,000$ of pretax income, this household has $\$ 717$ to deposit. The family uses the portfolio allocation shown in Table 3, putting 90 percent of the funds into stocks and the balance into bonds. Interest on the bonds is taxed as ordinary income; the interest net of taxes is reinvested in the account. After eighteen years, the account will have grown to $\$ 2,288$, with 44 percent of the account's value consisting of unrealized capital gains. At the end of year eighteen, one-quarter of the account balance is withdrawn to pay for college. Capital gains taxes are paid on the 44 percent of this withdrawal that represents unrealized capital gains. After four years of withdrawals, the account is empty. Taking into account income and payroll taxes, as well as taxes on interest and capital gains, a family following the investment path just described nets $\$ 1,456$ on its $\$ 1,000$ in pretax saving, as shown in Figure 1 .

The tax-advantaged vehicles, including the 529 and ESA, increase returns by reducing or eliminating the taxes assessed before the initial deposit, during the inside buildup, and/or at withdrawal. The return for each of these vehicles is shown in Figure 1. Below, I briefly discuss the tax advantages conferred by each of these vehicles.

The UTMA account shifts assets into the child's name and, thereby, the child's lower tax bracket. The initial pretax savings are taxed at the parent's rate, and so $\$ 717$ is deposited into the UTMA, as was

\footnotetext{
${ }^{17}$ The earnings portion of such early withdrawals from a Roth IRA is subject to taxation as ordinary income. As a result, the Roth is not an advantageous vehicle for college savings if its use requires early withdrawal and I do not discuss the Roth further in this paper.
} 
true for the parental account discussed above. Going forward, however, dividends, interest and capital gains are taxed at the child's lower rate. For a family with household income of $\$ 50,000$, these tax advantages translate into a slightly higher return on the UTMA than a parental account. This family yields $\$ 1,511$ in a UTMA, just four percent more than in a parental account. This small advantage is explained by the fact that parents in this bracket face taxes only slightly higher than those levied on their children.

A 529 savings account greater tax advantages than the UTMA, as the taxes on the inside buildup and withdrawals are not just reduced but eliminated. In a state that does not allow families to deduct 529 deposits from taxable income, $\$ 1,000$ of pretax income translates into the same $\$ 717$ deposit that was placed in the parental account and UTMA. But because there are no taxes on the inside buildup, by the time the child enters college the family has a slightly higher balance in a $529(\$ 2,467)$ than they would in a parental account $(\$ 2,042)$ but less than they would in a UTMA $(\$ 2,870)$. The advantage of the 529 grows as the family begins to draw down the funds and is exempted from any taxes on the resulting capital gains realizations. Accounting for these taxes, the family nets a $\$ 1,808$ return on its $\$ 1,000$ in pretax savings, 24 percent more than in a parental account and 20 percent more than a UTMA.

The ESA confers the same tax advantages as the 529 without an upfront deduction and, therefore, yields the same return. ${ }^{18}$ For the two vehicles, post-tax income is allowed to grow tax free, and withdrawals are untaxed. The IRA is the mirror image of these two instruments, in that there are no upfront taxes on the $\$ 1,000$ deposit, no taxes on the inside buildup, but withdrawals are taxed as ordinary income. The IRA therefore yields the same return as the ESA and a 529 without a state deduction, producing a return 24 percent greater than a non-advantaged parental account.

The option with the highest return is a 529 in a state that allows deposits to be deducted from state taxable income. For a given $\$ 1,000$ in pretax income, more can be deposited into this account than is true for a non-deductible 529 or ESA: with the typical state tax rate on earned income of 6.43 percent, the initial deposit is $\$ 760$, rather than $\$ 717$. Going forward, the tax treatment is the same as for a standard

\footnotetext{
${ }^{18}$ A key difference, however, is that much larger amounts can be deposited into a 529 than an ESA.
} 
529 or ESA. The 529 with an upfront deduction yields a return of $\$ 1,976,36$ percent more than a nonadvantaged account in the parent's name.

As these calculations make clear, the education savings account provide new and substantial tax advantages. The 529 with the upfront reduction offers a higher return than any existing investment option. Further, the 529 and ESA, while yielding the same after-tax return as the IRA, substantially expand the assets that can be shielded from taxation. Finally, since the 529 has no eligibility requirements, it provides the first opportunity for tax-advantaged saving for those families ineligible for the IRA or ESA due to their high incomes or their access to a pension program at work.

\section{VARIATION IN THE BENEFIT OF THE ESA AND 529 ACROSS INCOME GROUPS}

The previous section calculated the financial return to the education savings accounts for a single tax bracket. However, the tax advantages vary with income. First, those facing high marginal tax rates benefit more from sheltering income from taxation than do those with low marginal tax rates. Second, the expected value of the education savings accounts depends on the probability that the child actually goes to college. Finally, returns for lower-to-middle-income families are affected by the way the financial aid system treats the tax-advantaged education savings accounts. In this section, I address each of these issues in turn.

Variation in the Value of the Education Savings Accounts Due to Marginal Tax Rates

In this section, I examine the advantages of the education savings accounts for a range of household incomes, ranging from the lowest federal tax bracket (household income of $\$ 35,000$ or less) to the highest (household income of over $\$ 335,000$ ). The groups and their associated state and federal tax rates on earned income, capital gains, and interest are shown in Table 2.

I first show how returns vary by income in our benchmark, a non-advantaged account held in the name of the parent. In Figure 2, and Table 5, we see that the lowest-income household has the highest absolute returns. This is due to this group's relatively low tax rates on two types of income. First, this 
group's lower marginal tax rates on earned income produce a larger deposit for a given $\$ 1,000$ of pre-tax income: they start with $\$ 773$ in principal, compared to $\$ 572$ for the highest-income family. This difference in the upfront taxation of income accounts for most of the variation across income groups in net returns. Second, and of lesser import, the lowest-income household faces the lowest marginal tax rates on capital gains, dividends and interest. Between these two factors, after-tax returns drop as income rises. The highest-income household earns an after-tax return of $\$ 693$ on its pretax savings of $\$ 1,000$, while the lowest-income household earns 2.5 times as much, or $\$ 1,706$.

By eliminating some forms of taxation, the tax-advantaged vehicles flatten this income gradient in after-tax returns. Figures 3 and 4 show the after-tax return on the ESA and 529 for each income group. Figure 3 scales the returns relative to the return in the non-advantaged account for that income group. Figure 4 shows the returns in dollar terms. Note that since the returns for the ESA, 529 without an upfront deduction, and the IRA are identical, I have collapsed them into one category. ${ }^{19}$

The largest increases in returns accrue to the highest income group, both in dollar terms (Figure 4) and relative terms (Figure 3). For those in the top federal tax bracket, the 529 with an upfront deduction delivers a net return twice as high as that on a non-advantaged account. The 529 without an upfront deduction and the ESA net an after-tax return 79 percent higher than funds held in a nonadvantaged account, and 24 percent higher than funds held in a UTMA. For those in the lowest bracket, the proportional increases are much lower: the return on a 529 with an upfront deduction is 28 percent higher than that on a non-advantaged account. The corresponding figure is 19 percent for the ESA and 529 with no upfront deduction. Note that the UTMA does not benefit this lowest-income household, since the child and parent are in the same low tax bracket.

\footnotetext{
${ }^{19}$ It should be recalled, however, that the contribution limits are far higher on the 529 than the ESA or IRA, leading the 529 to be particularly advantageous to those who save above the ESA or IRA limits, or who participate in a retirement plan at work and are above the associated IRA income limits. Also, note that those married households with AGI above $\$ 220,000$ do not qualify for the ESA but do qualify for the 529.
} 
These calculations make clear that both the relative and absolute advantages of the education savings accounts rise steeply with income. At the bottom of the income distribution, where marginal tax rates are the lowest, the new accounts offer after-tax returns 19 to 28 percent higher than that on a nonadvantaged account. For an initial pretax investment of $\$ 1,000$, this translates into an additional return of $\$ 320$ to $\$ 482$. In the top tax bracket, the new accounts offer after-tax returns 79 to 101 percent higher than that on a non-advantaged account. For an initial pretax investment of $\$ 1,000$, this translates into an additional return of $\$ 545$ to $\$ 698$. The income gradient of returns is much flatter for the 529 and ESA than for other accounts. While in a non-advantaged account the lowest-income family earns 2.5 as much as the highest-income family, the ratio for funds held in a 529 or ESA is about 1.6.

\section{Variation in the Value of the Education Savings Accounts Due to College-Going Propensities}

The previous sections have shown that the 529 and ESA can confer substantial financial advantages. However, the education savings accounts have a downside that distinguishes them from other investment options: their tax benefits are contingent on the funds being used for educational expenses. If funds are put into one of these accounts and the child does not go to college, the net return on assets are reduced. This section examines how this penalty affects the value of the education savings accounts relative to other savings options, and how the value of this penalty varies by income.

I first describe the statutory limits on the use of funds in each savings vehicle. In order to yield the after-tax returns discussed in the previous section, the 529 and ESA must be used only for educational expenses, with 529 use limited to postsecondary expenses. Expenses are quite broadly defined to include tuition, fees, books, other school supplies, and living expenses. Withdrawals not used for these "qualified educational expenses" lose tax advantages. For both the 529 and ESA, the earnings portion of a withdrawal that is not used for qualified expenses is taxed as ordinary income, plus a federal penalty that 
consists of 10 percent of the account's earnings. ${ }^{20}$ ESA non-qualified withdrawals can only be made by the beneficiary and are taxed at the beneficiary's rate.

States use two approaches in dealing with non-qualified withdrawals. In some states, such as Utah, non-qualified distributions from a 529 can be directed to either the owner or beneficiary, with the taxes paid by whoever receives the funds. ${ }^{21}$ This allows non-qualified distributions to be taxed at the child's (presumably lower) rate. In other states, such as Illinois, the withdrawal must be taxed at the owner's rate. ${ }^{22}$ A review of the plan documents of a dozen large states shows an even split between these two approaches. As I will show below, the approach taken has a large impact on after-tax returns, especially for upper-income families.

Funds held in a parental account, UTMA, or IRA can be used much more flexibly than those in a 529 or ESA. The parental account can be used for any expense. UTMA withdrawals by the parent are limited to those that benefit the child, but this definition is quite broad. Funds can be withdrawn from the Traditional IRA before age 591/2 without incurring a 10 percent penalty if they are used for postsecondary expenses, the purchase of a first home, disability, or excessive medical expenses. ${ }^{23}$

Relative to the non-advantaged account, UTMA and IRA, then, the ESA and 529 are more risky for families in which the college attendance of the children is uncertain. In order to quantify this risk, I first calculate the return to non-qualified use of the various college saving options. In these calculations, I

${ }^{20}$ An exception is granted if the child attends college and receives a scholarship. In this case, actual costs plus the value of the scholarship are treated as qualified expenses. If a child chooses not to attend college, the parent can also change the beneficiary of the 529 or ESA to a relative. "Relative" includes previous generations (parents or ancestors of parents, siblings of parents), the current generation (spouse, siblings and their spouses, first cousins) and the next generation (children and their spouses, children of siblings).

21 "All non-qualifying refunds will be taxed to the participant or beneficiary, depending on who receives the refund, and will be reported to the appropriate taxing authorities in the year they are made." Accessed at the Utah Education Savings Plan website on March 14, 2004. See http://www.uesp.org/QUESTIONS ANSWERS/questions answers.html.

22 "[T] he earnings portion of withdrawals or distributions from an Account other than Qualified Withdrawals... are includable in computing income of the Account Owner for federal income tax purposes..." See Bright Start College Savings Program (2004), p. 47.

${ }^{23}$ While one can make withdrawals from an IRA for college, one can't do so from a 401(k), though one can take a loan from the $401(\mathrm{k})$ account. 
assume that the family follows the same investment strategy as a family that sends the child to college, but rather than begin withdrawals at age 18 the funds are held until the child is age 22, at which point the family decides that the child is not going to college and empties the account. ${ }^{24}$ Note that the returns change for all savings options, not just the 529 and ESA, when the accounts are not used for college. This is because holding the funds for 22 years rather than beginning withdrawals at year 18 produces more earnings in the last four years of the investment horizon. The returns to non-college use are shown in Table 5.

Due to the penalty and income tax on non-qualified withdrawals, returns on the ESA drop substantially (Table 5). However, the impact of the penalty differs across income groups. Recall that 1) the earnings portion of withdrawals is taxed at the beneficiary's rate and 2) the penalty is not assigned proportional to a household's tax rate but is a fixed proportion (10 percent) of earnings. Relative to the large tax savings that high-income families gain by shifting income into their children's tax bracket, the 10 percent penalty is small. Relative to the small tax savings that low-income families gain by shifting income into their children's tax bracket, the 10 percent penalty is large. As a result, the penalty for nonqualified withdrawals makes the ESA a worse deal than other investment options for low-income families, but leaves it still relatively attractive for high-income families. ${ }^{25}$

In particular, the upper four brackets are still better off in an ESA than in a UTMA or nonadvantaged account, even once the penalty for non-qualified use is assessed. Returns are 11 to 24 percent higher than in a non-advantaged account [Figure 5]. By contrast, once a penalty for non-qualified use is assessed, those in the two lower brackets are worse off in the ESA than they would have been in a nonadvantaged account. For example, those in the lowest bracket earn 11 percent less than they would in a

\footnotetext{
${ }^{24}$ The calculations also assume that the state in which the 529 is held does not attempt to recapture the value of any upfront deduction. At least one state, Illinois, has shown a willingness to recapture the deduction under some circumstances; that state penalizes families that have taken the Illinois deduction but subsequently moved funds to another state's 529 .

${ }^{25}$ Note that this observation applies to the penalty assessed for early withdrawal of funds from individual retirement accounts. There, too, a fixed penalty of 10 percent is applied, and this penalty will hit those in the lower brackets relatively harder than those in the upper brackets.
} 
non-advantaged account, if the funds are not used for college. Most strikingly, those in the top tax bracket gain a larger advantage from non-qualified use of an ESA (24 percent above their return in a nonadvantaged account, see Figure 5) than those in the bottom bracket gain from qualified use (19 percent, see Figure 3).

This discussion carries over to the 529, for those states that allow non-qualified payments from 529 accounts to be made to the child. In these states, parents can shift income to their child's lower tax bracket, with high-income families netting substantial gains even when the accounts are used for noneducational purposes. This avenue is closed in states that require non-qualified 529 withdrawals to be claimed by the account owner, thereby forcing earnings to be taxed at the parent's higher tax rate. A review of the plan documents of a dozen large state 529 programs found an even split between the two treatments of non-qualified withdrawals.

Figure 6 shows the impact on returns of these two different approaches to taxing non-qualified 529 withdrawals. Allowing withdrawals to be taxed at the child's rate produces a patterns of relative returns that rise with income: when the funds are used for non-educational purposes, those in the lowest tax brackets are worse off in a 529 than they would be in a non-advantaged account while those in the upper brackets are better off. Forcing withdrawals to be taxed at the parent's rate produces the opposite pattern. In this case, everyone using funds for non-educational purposes is worse off in a 529 than a nonadvantaged account, but the higher brackets are hardest hit. While the lowest tax bracket yields 89 percent of the return that it would in a non-advantaged account, the highest bracket yields just 67 percent.

As these calculations make clear, this is a place where program design is quite important. The penalty was created out of a concern that some households might strategically shelter large sums in the education savings accounts, without any intent of using them for college. Given that families in the top brackets are more likely to have significant assets to shelter, it is sensible to create a penalty structure that discourages them from using the education saving accounts for unintended purposes. However, as the ESA penalty (and the 529 penalty in those states that assign non-qualified withdrawals to the child's income) is structured, those in the upper brackets can still benefit substantially from the education savings 
accounts even when they do not use them for their intended purposes. By contrast, those in the lower brackets, who generally have few assets to shelter and who are unlikely to engage in such strategic tax avoidance, always face a lower return if the accounts are not used for educational purposes.

\section{Variation in the Value of the Education Savings Accounts Due to the Financial Aid Tax}

A final source of variation across income groups in the value of the education savings accounts is the treatment of household assets in the determination of need-based financial aid for college. ${ }^{26}$ The intent of the need-based financial aid system is to give more aid to those with fewer resources. Both assets and asset earnings are considered resources by the need-based aid formula, so each dollar increase in assets and asset earnings leads to a proportional reduction in financial aid. In this sense, the aid system "taxes" assets and asset returns of families potentially eligible for need-based aid. ${ }^{27}$ Key to the present analysis is that this aid tax varies across savings instruments.

One might dismiss the aid tax as irrelevant by noting that the poor get aid but do not save, and the rich save but do not get aid. This common wisdom is wrong, as there is substantial overlap in the income distributions of those who save and those who get aid. First, note the 50 percent of those households holding 529 and ESA accounts have incomes below \$81,000. Second, tabulations of the 2000 National Postsecondary Aid Survey (NPSAS) indicate that a substantial proportion of families with incomes above $\$ 80,000$, and even $\$ 100,000$, receive need-based aid, in the form of both grants and loans. Many of these students are at expensive, four-year colleges, which provide their own need-based grants to students.

What kind of family is affected by the aid tax? Given the historically-high level of tuition prices, relatively well-off families qualify for need-based aid, and so face this tax. This is particularly true if the

\footnotetext{
${ }^{26}$ This section uses results from Dynarski (2003). See that paper for detailed calculations and more information on the financial aid system and its treatment of different savings vehicles.

${ }^{27}$ See Edlin (1993) and Feldstein (1995) for more discussion of the aid tax.
} 
student attends a private college, or if a family has multiple students in college at the same time. ${ }^{28}$ As this section will show, families all along the income distribution fall into this category.

For two kinds of families, however, the aid tax is zero. The first type of family is extremely needy (as defined by the need-based aid system) and receiving the maximum aid allowed. ${ }^{29}$ As a result, a marginal decrease in this family's assets will not increase their aid, nor will a marginal increase in their assets decrease their aid. Since there is no link between assets and aid for this family, their aid tax is zero. The second type of family is at the other end of the spectrum: this family is very well off (again, as defined by the need-based aid system) and receiving no aid. Again, marginal changes in assets will not affect this family's aid eligibility. Any family that is not at one of these two extremes of need is subject to the aid policies described in this paper.

Low-income families are most likely to receive aid, and get the largest aid packages. Among students with family incomes below $\$ 40,000,79$ percent receive need-based aid, averaging $\$ 6,904 .^{30}$ However, it is also clear that middle- and even upper-income families are quite likely to receive substantial amounts of aid. Of students from families with incomes of $\$ 40,000$ to $\$ 70,000,53$ percent receive need-based aid in the form of grants, loans or work-study, with the aid of recipients averaging $\$ 5,988$. Moving up the income distribution, 32 percent of students from families with incomes of $\$ 70,000$ to $\$ 100,000$ receive need-based aid averaging $\$ 5,288$. Even in the highest income group, 18 percent are receiving some form of need-based aid, averaging $\$ 4,844$.

The composition of this need-based aid varies considerably across the income groups. While 63 percent of students from families with income below $\$ 40,000$ receive a Pell Grant averaging \$2,290, only eight percent of students from families with incomes of $\$ 40,000$ to $\$ 70,000$ receive a Pell, and no

\footnotetext{
${ }^{28}$ A family that has multiple children in college at a given point in time will be eligible for more needbased aid than if those children attended college in sequence.

${ }^{29}$ Total aid is capped by a student's actual schooling costs, which includes tuition and fees plus an allowance for such items as food, rent and other living expenses.

${ }^{30}$ These data are for full-time, dependent, non-foreign undergraduates attending college in academic year 1999-2000, and are taken from the 1999-2000 National Postsecondary Aid Survey (NPSAS).
} 
students in higher income categories. While the Pell is heavily concentrated among low-income students, the story is quite different for other forms of need-based aid. Colleges and universities, especially the more-expensive private schools, distribute their own need-based scholarships. Among students with family income between $\$ 40,000$ and $\$ 70,000,25$ percent receive need-based grants from their schools, with the grant of recipients averaging $\$ 4,034$. Even among families with incomes above $\$ 100,000,11$ percent receive need-based grants from their schools averaging $\$ 4,591 .^{31}$

Many middle-and upper-income students also qualify for the need-based Stafford Loan. While loans are obviously less valuable than grants, the need-based Stafford (also known as the subsidized Stafford) has very attractive terms. The subsidy value of a Stafford loan is currently about thirty cents on the dollar. ${ }^{32}$ In the $\$ 40,000$ to $\$ 70,000$ income range, 23 percent of students receive a subsidized Stafford loan averaging $\$ 3,127$. In the highest income category the figures are 9 percent and $\$ 3,227$, respectively.

Many of the families who receive need-based aid will be on the margin of getting more aid - that is, an increase (decrease) in their financial resources will decrease (increase) the amount of aid for which they are eligible. As noted earlier, this includes any family that is not getting the maximum aid allowable given their schooling costs. Such families are subject to the aid policies I describe in the paper.

Briefly, the aid tax has two components: a tax on asset balances and a tax on asset earnings, with the magnitude of each tax depending on the type of asset. Table 6 lists the components of the aid tax for various savings vehicles. To illustrate how the aid tax works, let us consider a non-advantaged account

\footnotetext{
${ }^{31}$ Most schools follow the federal formulas described in this paper in distributing their own need-based grant. Eighty-seven percent of four-year public schools and 57 percent of four-year private schools use the federal formula in distributing their own need-based grants (National Association of Student Financial Aid Administrators and the College Board (2002).

${ }^{32}$ See Dynarski (2002). The bulk of the subsidy arises from the government paying the interest on the loan while the student is in school. The subsidy value on the Stafford is at a historical low, since market interest rates are quite low. As market interest rates rise, so too does the subsidy value. The subsidy value rises especially rapidly when market rates exceed the statutory rate cap of 8.25 percent, as above this rate the government assumes all interest rate risk.
} 
held in the name of the parent. The annual tax on asset balances, in this case, is 5.64 percent. ${ }^{33}$ If the child goes to college for just one year, this 5.64 percent is the (marginal) aid tax on asset balances for this family. However, for each year of college, the asset balance is again taxed at the 5.64 percent rate. ${ }^{34}$ Assuming a student attends college for four years, a given dollar in assets held for this entire period is taxed at a rate of 21 percent $\left[=1-(1-0.0564)^{4}\right]$. This is the aid tax rate on balances in accounts considered to be owned by the parent (excluding retirement accounts and home equity, whose balances are not taxed). Balances in accounts considered to be owned by the student are taxed at a rate of 35 percent, or 82 percent over four years of college.

Any earnings from the non-advantaged account are also taxed, if they arrive in a year whose income is considered in determining college aid. ${ }^{35}$ The aid tax rate on asset earnings (net of any income taxes) is 47 percent for a non-advantaged account held by the parent. This tax is applied to both earnings accruals and to any earnings realized upon withdrawals from the account. Note that, in an account that has been building value for 18 years, a substantial portion of the balance will consist of unrealized earnings. In a non-advantaged account, given the investment scenario we have been assuming throughout the paper, unrealized earnings will represent about 44 percent of account value. As the account is drawn down for college, earnings will be realized and after-income-tax realizations assessed by the aid formula.

Table 7 and Figure 7 show the impact of the aid tax on after-tax returns for various savings vehicles. In the first column is the return on a given savings vehicle for a household that is unaffected by

\footnotetext{
${ }^{33}$ This tax rate is a function of the family's overall financial position, as summarized by the family's "adjusted available income" (AAI). AAI is a weighted sum of income and assets, net of allowable expenses, including taxes. The AAI tax is progressive and steep, with little distance between the lowest and highest tax rate. The lowest rate applies to an AAI of $\$ 11,000$, while the schedule tops out at an AAI of $\$ 24,000$. In the calculation of aid taxes, I assume that families are at the top of this schedule.

${ }^{34}$ For each year of college, the child must reapply for aid, providing a newly-competed set of aid and income tax forms.

${ }^{35}$ Tax returns from the previous year are used to report income for the purposes of determining financial aid determination, so income is considered with a lag. For a child who attends college for four years, asset income received in the senior year of high school and first three years of college will be subject to the aid tax.
} 
the aid tax; these are the returns we have seen in earlier tables. In the second column of Table 7 are returns net of the aid tax. I assume, as I have throughout the paper, that funds are drawn down over the four years of college. These results are not shown for the top two tax brackets, in which I assume household income is sufficiently high (above $\$ 196,400$ ) that the child is beyond the margin of eligibility of need-based financial aid at even the most expensive institutions. Columns (3) and (4) express the aid tax as a percent of the asset balance at the start of college and as a percent of the after-income-tax return, respectively.

As Figure 7 makes clear, the college savings vehicles provide higher net returns than any other investment option for those who are on the aid margin. If an aid-marginal child applies to college with funds in an ESA or 529, over the course of her college career she will lose about fifteen cents in aid for each dollar she holds in her education savings account. By contrast, if the money was held in her parents IRA, she would lose 26 to 33 cents for each dollar of assets and if it was held in a non-advantaged account belonging to her parents she would lose 40 to 45 cents.

Most dramatically, each dollar held in a UTMA would reduce aid by over a dollar over the course of a college career. That is, for the UTMA, returns net of the aid tax are negative. When we consider only income taxes, an aid-marginal family with household income of $\$ 50,000$ that puts $\$ 1,000$ pretax dollars in a UTMA nets a return of $\$ 1,511$. This return is four percent higher than if the funds were invested in a non-advantaged account. But once we consider the aid tax, this small financial advantage disappears. The final return on the $\$ 1,000$ pretax investment, net of income and aid taxes, is $-\$ 1,360$. This family loses all principal and all earnings, plus an additional $\$ 360$, to the aid and income taxes.

Until early 2004, the ESA was treated the same as the UTMA in the calculation of financial aid. As shown in Dynarski (forthcoming), this resulted in negative returns on the ESA for aid-marginal families, with all principal and earnings lost to income and aid taxes. The US Department of Education released new rules that alter the treatment of the ESA, bringing it in line with that of the 529 savings plans. While the ESA was once considered an asset of the child, it is now considered an asset of the parent, like the 529. Further, the earnings portion of ESA withdrawals no longer counts as income for the 
purposes of calculating financial aid. As a result of these provisions, the 529 savings plans and ESA now receive the most favorable treatment by the aid system of all the investment options we have considered.

The IRA, the next best option, fares relatively poorly because after-tax withdrawals from the IRA are counted as income in the aid formula. For example, a family with $\$ 50,000$ in income nets an after-tax return of $\$ 1,808$ in an IRA, the same as the return in an ESA or a 529 without an upfront deduction. Once the aid tax is considered, however, the return on the IRA drops to $\$ 844$ while that on the education savings accounts drops only to $\$ 1,441$. A non-advantaged account fares even worse, because unlike the IRA the asset balance, as well as withdrawals, is considered in the calculation of aid. For our aid-marginal family with $\$ 50,000$ of income, a non-advantaged account yields just $\$ 449$ after income and aid taxes.

There are two conclusions to draw from these figures. First, the aid tax reduces asset returns, including those in the college savings accounts, for those on the margin of getting more or less financial aid. Because low- to middle-income families are more likely to be on the aid margin than high-income families, the aid tax therefore contributes to the concentration of the benefits of the 529 and ESA among those in the highest tax brackets. Second, the 529 and ESA now provide greater shelter from the aid tax than any other financial instrument. ${ }^{36}$ For aid-marginal families in the middle two brackets, the ESA and 529 more than undo the aid tax. A family with $\$ 100,000$ in income that is subject to the aid tax nets about 20 percent more in an ESA than it would if it did not face the aid tax and held its funds in a nonadvantaged account. By contrast, for those aid-marginal families in the bottom two tax brackets, the ESA (and 529 without a deduction) comes just shy of undoing the aid tax. The return on the ESA for an aidmarginal family with income of $\$ 50,000$ is just below the return of a non-advantaged account with an aid tax of zero [ $\$ 1,441$ and $\$ 1,456$, respectively; see Table 8$]$.

\footnotetext{
${ }^{36}$ Home equity is fully sheltered from the aid tax.
} 


\section{DISCUSSION AND CONCLUSION}

The discussion so far has focused on differences in the net returns to the education savings accounts and alternative savings vehicles. Before summarizing those differences and closing the paper, I would like to touch on some other key differences between these various investment options. The first difference is that of the degree of control that parents have over the funds. Parents may wish to control how savings are spent, and for them this preference may trump tax advantages. For example, if funds in a UTMA are not spent on college, they still go the child eventually; the parent cannot take back UTMA funds. The same holds for the ESA: the funds cannot be taken back. ${ }^{37}$ When an ESA beneficiary reaches age 30 , the funds are automatically released to the beneficiary as a non-qualified withdrawal. These limitations in the degree of parental control may make the ESA and UTMA unattractive to some parents, even if they offer the highest return of the available options.

A parent can hold more control over their children's use of funds by using a 529. A 529 account owner can change the beneficiary, as is true with the ESA, but can also liquidate the account and pocket the funds, albeit after paying taxes and a penalty. A non-tax-advantaged account held in the parent's name offers no shelter from income and aid taxes, but it gives the account owner the most control over when and for whom to disburse the funds.

A related difference between the various savings vehicles is their option value. Funds held in a non-advantaged account can be used for any purpose, with no penalty, should a child choose not to attend college. Similarly, funds can be left in an IRA, with the tax deferral on earnings continuing until retirement. By contrast, the 529 and ESA have relatively limited option value, since they can be used for non-educational purposes only after paying a penalty.

Behavioral economics may also shed light on how parents choose a savings vehicle. From the behavioral standpoint, the penalty for non-qualified use may be perceived as a benefit rather than a drawback, as it helps to commit parents to hold funds for college rather than use them for current

\footnotetext{
${ }^{37}$ The account owner can, however, select a new beneficiary who is a relative of the previous beneficiary and under 30 years old.
} 
consumption or to pay off debt. In this way, the ESA and 529 resemble the IRA and 401(k), which commit workers to save for retirement or face a penalty for early withdrawal of funds. Also in order to commit themselves to a certain spending pattern, parents may also like to have separate savings accounts for different purposes, such as retirement and education, even if this comes at some cost. ${ }^{38}$ This is the mirror image of the fungibility discussion in the previous paragraphs. A non-advantaged account offers the most freedom for the account owner, but this very freedom will be seen as a drawback by parents whose saving behavior is characterized by mental accounting.

I have found that the advantages of the 529 and ESA rise sharply with income, for three reasons. First, those with the highest marginal tax rates benefit the most from sheltering income, gaining most in both absolute and relative terms. This distributional impact of the 529 and ESA is the same as that on all tax-advantaged savings vehicles, including the IRA and 401(k).

The second reason that the advantages of the ESA and 529 rise with income is more subtle and is driven by the fact that the 529 and ESA are education saving incentives. Both vehicles reward those who save and use their savings for postsecondary education. Both vehicles include provisions that punish those who do not use the funds for education. There is therefore some risk associated with using these accounts, as net returns are substantially reduced if the beneficiary does not use the funds for schooling. The treatment of non-qualified withdrawals from the ESA, and from the 529s of some states, further tilts the benefits of these accounts toward upper-bracket families. Non-qualified withdrawals from the ESA are assigned to the beneficiary for tax purposes, and so face the child's lower tax rate. As a result, those in the top tax brackets gain a larger advantage from non-qualified use of an ESA than those in the bottom bracket gain from qualified use.

Given that the penalty was created out of a concern that some households might strategically shelter large sums in the education savings accounts, without any intent of using them for college, the choice of penalty structure is important. Families in the top brackets, who are more likely to have

${ }^{38}$ Thaler (1999) provides a discussion of mental accounting and its impact on individuals' financial decisions. 
significant assets to shelter, can still benefit substantially from the ESA and, in some states the 529, even when they do not use them for their intended purposes. By contrast, those in the lower brackets, who generally have few assets to shelter and who are unlikely to engage in such strategic tax avoidance, consistently face a lower return if the accounts are not used for educational purposes. Requiring that the earnings portion of non-qualified withdrawals from the ESA and 529 be taxed at the parents' tax rate would help to undo this perverse incentive structure. An additional option is to assess a penalty proportional to the account owner's tax rate, rather than the current flat penalty of 10 percent of earnings.

Finally, the college financial aid system taxes away the advantages of the 529 and ESA for those low- and middle-income families that are on the margin of receiving aid. While the income tax system disproportionately penalizes low-income 529 and ESA beneficiaries who do not go to college, the aid system reduces returns on the 529 and ESA for those who do go to college. The need-based financial aid system reduces aid when a family holds assets, including those in the college savings accounts, for those on the margin of getting more or less financial aid. Because low- to middle-income families are more likely to be on the aid margin than high-income families, the aid tax therefore contributes to the concentration of the benefits of the 529 and ESA among those in the highest tax brackets. While the aid tax does reduce returns on all financial assets for those in the lower tax brackets, the 529 and ESA do provide greater shelter from the aid tax than any other financial instrument. 


\section{References}

Cerulli Associates.

The State of the College Savings Market: 529 Plans in Perspective. The Cerulli Report. Boston, MA: Cerulli Associates, Inc, 2001.

Cerulli Associates.

A Competitive Outlook for 529 Savings Plans. The Cerulli Report. Boston, MA: Cerulli

Associates, Inc, 2003.

U.S. Department of the Treasury. Internal Revenue Service.

Tax Rules for Children and Dependents (Publication 929). Washington, D.C.: Department of the Treasury, 2003.

Dick, Andrew, and Aaron Edlin.

"The Implicit Taxes from College Financial Aid." Journal of Public Economics 65 No. 3 (September, 1997): 295-322.

Dynarski, Susan.

"Loans, Liquidity and Schooling Decisions." Kennedy School of Government Working Paper. Cambridge, MA: Harvard University, 2002.

Dynarski, Susan.

"Tax Policy and Financial Aid Policy: Collision or Coordinarion? A Case Study of the 529 and Coverdell Savings Incentives." Tax Policy and the Economy 18, (forthcoming).

Edlin, Aaron.

"Is College Financial Aid Equitable?" Journal of Economic Perspectives 7 No. 2 (September, 1993): 143-158.

Feenberg, Daniel Richard, and Elizabeth Coutts.

"An Introduction to the TAXSIM Model." Journal of Policy Analysis and Management 12 No. 1 (Winter 1993): 189-194.

Feldstein, Martin.

"Scholarship Rules and Private Savings." American Economic Review 85 No. 3 (June, 1995): 552-66.

Illinois State Treasury. Bright Start Savings Program.

Program Disclosure Statement and Participation Agreement. Chiacgo, IL: Illinois State Treasury (2004).

TAXSIM Version 5.

Cambridge, MA:National Bureau of Economic Research. (at http://www.nber.org/taxsim).

Thaler, Richard.

"Mental Accounting Matters." Journal of Behavioral Decision Making 12 (1999): 183-206.

Turner, Sarah. 
"Going to College and Finishing College: Explaining Different Educational Outcomes." In College Choices: The Economics of Which College, When College, and How to Pay For It, edited by Caroline Hoxby. Chicago: Chicago University Press, (forthcoming). 
Table 1

Characteristics of Education Savings Account Investor

Households with Children

2001 Survey of Consumer Finances

\begin{tabular}{|c|c|c|c|c|c|}
\hline & $\begin{array}{l}\text { All Households } \\
\text { w/ Children } 16 \\
\text { and under } \\
\text { (1) }\end{array}$ & $\begin{array}{c}\text { Education } \\
\text { Savers } \\
\text { (529 or ESA) }\end{array}$ & $\begin{array}{c}\text { Retirement } \\
\text { Savers } \\
\text { (IRA or Keogh) }\end{array}$ & $\begin{array}{l}\text { Education } \\
\text { Savers } \\
\text { vs. } \\
\text { Retirement } \\
\text { Savers } \\
(4) \\
\end{array}$ & $\begin{array}{c}\text { Education } \\
\text { Savers } \\
\text { vs. } \\
\text { All Households } \\
\\
\text { (5) } \\
\end{array}$ \\
\hline Has 529 or ESA & $3 \%$ & $100 \%$ & $5 \%$ & - & - \\
\hline Has IRA or Keogh & $38 \%$ & $70 \%$ & $100 \%$ & - & - \\
\hline Median Income & 50,000 & 91,000 & 75,000 & 16,000 & 41,000 \\
\hline Median Net Worth & 61,830 & 281,200 & 227,600 & 53,600 & 219,370 \\
\hline Mean Balance in IRA accounts & $\begin{array}{c}20,132 \\
(108,599)\end{array}$ & $\begin{array}{c}89,400 \\
(276,948)\end{array}$ & $\begin{array}{c}56,523 \\
(174,129)\end{array}$ & $\begin{array}{c}32,877 \\
(28,073)\end{array}$ & $\begin{array}{c}69,268 \\
(17,480)\end{array}$ \\
\hline Mean Balance in 529 Accounts & $\begin{array}{c}126 \\
(2,239)\end{array}$ & $\begin{array}{c}4,664 \\
(12,951)\end{array}$ & $\begin{array}{c}148 \\
(3,045)\end{array}$ & $\begin{array}{l}4,516 \\
(694)\end{array}$ & $\begin{array}{l}4,538 \\
(465)\end{array}$ \\
\hline Age of Oldest Parent & $\begin{array}{l}38.78 \\
(8.50)\end{array}$ & $\begin{array}{l}40.98 \\
(6.59)\end{array}$ & $\begin{array}{c}41 \\
(8.05)\end{array}$ & $\begin{array}{l}-0.02 \\
(1.22)\end{array}$ & $\begin{array}{c}2.2 \\
(1.26)\end{array}$ \\
\hline Age of Oldest Child & $\begin{array}{l}10.71 \\
(5.88)\end{array}$ & $\begin{array}{c}9.42 \\
(5.23)\end{array}$ & $\begin{array}{l}10.46 \\
(5.74)\end{array}$ & $\begin{array}{l}-1.04 \\
(0.87)\end{array}$ & $\begin{array}{l}-1.29 \\
(0.88)\end{array}$ \\
\hline Number of Children & $\begin{array}{c}2.08 \\
(1.05)\end{array}$ & $\begin{array}{c}1.99 \\
(0.86)\end{array}$ & $\begin{array}{c}2.07 \\
(0.99)\end{array}$ & $\begin{array}{l}-0.08 \\
(0.15)\end{array}$ & $\begin{array}{l}-0.09 \\
(0.16)\end{array}$ \\
\hline Highest Education of Parents & $\begin{array}{l}13.89 \\
(2.49)\end{array}$ & $\begin{array}{l}16.19 \\
(1.18)\end{array}$ & $\begin{array}{l}14.91 \\
(2.30)\end{array}$ & $\begin{array}{c}1.28 \\
(0.34)\end{array}$ & $\begin{array}{c}2.30 \\
(0.37)\end{array}$ \\
\hline Parent BA or Higher & $\begin{array}{c}0.37 \\
(0.48)\end{array}$ & $\begin{array}{c}0.91 \\
(0.29)\end{array}$ & $\begin{array}{c}0.59 \\
(0.49)\end{array}$ & $\begin{array}{c}0.32 \\
(0.07)\end{array}$ & $\begin{array}{c}0.54 \\
(0.07)\end{array}$ \\
\hline $\mathrm{N}$ & 1533 & 46 & 588 & - & - \\
\hline
\end{tabular}

Ntoes: Standard deviations in parentheses in first three columns. Standard errors in parentheses in last two columns.

Imputation Two of SCF; weights used. 
Table 2

Marginal Tax Rates Used in Calculations

\begin{tabular}{|l|ccc|cc|cc|cc|}
\hline \multirow{2}{*}{$\begin{array}{c}\text { Household } \\
\text { Income }\end{array}$} & \multicolumn{3}{|c|}{ Earned Income } & \multicolumn{2}{c|}{ Capital Gains } & \multicolumn{2}{c|}{ Interest Income } & \multicolumn{2}{c|}{ Dividends } \\
\cline { 2 - 9 } & Federal & State & FICA & Federal & State & Federal & State & Federal & State \\
\hline$\$ 35,000$ & $10 \%$ & $5.65 \%$ & $7.65 \%$ & $5 \%$ & $4.83 \%$ & $10 \%$ & $5.65 \%$ & $5 \%$ & $5.65 \%$ \\
$\$ 50,000$ & $15 \%$ & $6.29 \%$ & $7.65 \%$ & $5 \%$ & $5.22 \%$ & $15 \%$ & $6.29 \%$ & $5 \%$ & $6.29 \%$ \\
$\$ 100,000$ & $25 \%$ & $6.43 \%$ & $1.45 \%$ & $15 \%$ & $5.61 \%$ & $25 \%$ & $6.43 \%$ & $15 \%$ & $6.43 \%$ \\
$\$ 150,000$ & $28 \%$ & $6.38 \%$ & $1.45 \%$ & $15 \%$ & $5.48 \%$ & $28 \%$ & $6.38 \%$ & $15 \%$ & $6.38 \%$ \\
$\$ 200,000$ & $33 \%$ & $6.40 \%$ & $1.45 \%$ & $15 \%$ & $5.56 \%$ & $33 \%$ & $6.40 \%$ & $15 \%$ & $6.40 \%$ \\
$\$ 335,000+$ & $35 \%$ & $5.08 \%$ & $1.45 \%$ & $15 \%$ & $4.41 \%$ & $35 \%$ & $5.08 \%$ & $15 \%$ & $5.08 \%$ \\
\hline
\end{tabular}

Notes: Federal rates are 2003 bracket rates. State rates are average of effective 2002 marginal rates calculated from NBER TAXSIM. State averages taken across states that have an income tax. 
Table 3

Age-Based Portfolio Used in Return Calculations

\begin{tabular}{|c|c|c|c|c|c|c|c|c|c|c|c|}
\hline Year: & $1-3$ & 4-6 & $7-8$ & 9 & 10 & 11-12 & 13 & $14-15$ & $16-22$ & \multicolumn{2}{|c|}{ Nominal Rate of Return } \\
\hline Stock Share & $90 \%$ & $85 \%$ & $74 \%$ & $68 \%$ & $59 \%$ & $58 \%$ & $45 \%$ & $42 \%$ & $25 \%$ & $\begin{array}{l}\text { Capital Gains } \\
\text { Dividends }\end{array}$ & $\begin{array}{l}7 \% \\
2 \%\end{array}$ \\
\hline Bond Share & $10 \%$ & $15 \%$ & $26 \%$ & $32 \%$ & $41 \%$ & $42 \%$ & $55 \%$ & $58 \%$ & $75 \%$ & Bonds & $4 \%$ \\
\hline
\end{tabular}


Table 4

Tax Treatment of College Saving Alternatives

\begin{tabular}{|c|c|c|c|c|}
\hline Investment Option & $\begin{array}{c}\text { Income Limit } \\
\text { married, filing jointly }\end{array}$ & $\begin{array}{c}\text { Taxes Paid on Income, } \\
\text { pre-deposit } \\
\end{array}$ & Taxed Paid on Inside Build-up & Taxes Paid at Withdrawal \\
\hline 529 & & Federal and state, FICA. & & \\
\hline 529 with deduction & & Federal and FICA. & & \\
\hline Coverdell ESA & $\$ 220,000$ & Federal and state, FICA & & \\
\hline UTMA & & Federal and state, FICA & $\begin{array}{l}\text { Federal and state. } \\
\text { First } \$ 750 \text { untaxed } \\
\text { Child } 14+: \text { earnings }>\$ 750 \text { at child's rate } \\
\text { Child }<14 \text { : next } \$ 750 \text { at child's rate \& } \\
>\$ 1500 \text { at parent's rate }\end{array}$ & $\begin{array}{l}\text { Federal and state on realized } \\
\text { capital gains, child's rate }\end{array}$ \\
\hline $\begin{array}{l}\text { Non-Advantaged } \\
\text { Account, Parent }\end{array}$ & & Federal and state, plus FICA & Federal and state & $\begin{array}{l}\text { Federal and state on realized } \\
\text { capital gains }\end{array}$ \\
\hline Traditional IRA & $\begin{array}{l}\$ 70,000 \\
\text { No income limit if no work- } \\
\text { related retirement plan. }\end{array}$ & FICA & & $\begin{array}{l}\text { Federal and state on entire } \\
\text { withdrawal }\end{array}$ \\
\hline
\end{tabular}


Table 5

After-Tax Return to College Savings Options

\begin{tabular}{|c|c|c|c|}
\hline & College Use & \multicolumn{2}{|c|}{ Non-College Use } \\
\hline \multicolumn{4}{|l|}{$\overline{\text { ESA }}$} \\
\hline$\$ 35 \mathrm{~K}$ & $\$ 2,026$ & $\$ 1,682$ & \\
\hline$\$ 50 \mathrm{~K}$ & $\$ 1,808$ & $\$ 1,488$ & \\
\hline$\$ 100 \mathrm{~K}$ & $\$ 1,634$ & $\$ 1,334$ & \\
\hline$\$ 150 \mathrm{~K}$ & $\$ 1,511$ & $\$ 1,225$ & \\
\hline$\$ 200 \mathrm{~K}$ & $\$ 1,317$ & $\$ 1,053$ & \\
\hline$\$ 335 \mathrm{~K}+$ & $\$ 1,238$ & $\$ 983$ & \\
\hline \multicolumn{4}{|l|}{ UTMA } \\
\hline$\$ 35 \mathrm{~K}$ & $\$ 1,706$ & $\$ 1,896$ & \\
\hline$\$ 50 \mathrm{~K}$ & $\$ 1,511$ & $\$ 1,688$ & \\
\hline$\$ 100 \mathrm{~K}$ & $\$ 1,355$ & $\$ 1,521$ & \\
\hline$\$ 150 \mathrm{~K}$ & $\$ 1,245$ & $\$ 1,404$ & \\
\hline$\$ 200 \mathrm{~K}$ & $\$ 1,072$ & $\$ 1,218$ & \\
\hline$\$ 335 \mathrm{~K}+$ & $\$ 1,001$ & $\$ 1,142$ & \\
\hline \multicolumn{4}{|c|}{ Traditional IRA } \\
\hline$\$ 35 \mathrm{~K}$ & $\$ 2,026$ & $\$ 2,262$ & \\
\hline$\$ 50 \mathrm{~K}$ & $\$ 1,808$ & $\$ 2,027$ & \\
\hline$\$ 100 \mathrm{~K}$ & $\$ 1,634$ & $\$ 1,839$ & \\
\hline$\$ 150 \mathrm{~K}$ & $\$ 1,511$ & $\$ 1,707$ & \\
\hline$\$ 200 \mathrm{~K}$ & $\$ 1,317$ & $\$ 1,498$ & \\
\hline$\$ 335 \mathrm{~K}+$ & $\$ 1,238$ & $\$ 1,413$ & \\
\hline \multicolumn{4}{|c|}{ Non-Advantaged Account, Parent } \\
\hline$\$ 35 \mathrm{~K}$ & $\$ 1,706$ & $\$ 1,896$ & \\
\hline$\$ 50 \mathrm{~K}$ & $\$ 1,456$ & $\$ 1,623$ & \\
\hline$\$ 100 \mathrm{~K}$ & $\$ 1,068$ & $\$ 1,197$ & \\
\hline$\$ 150 \mathrm{~K}$ & $\$ 946$ & $\$ 1,064$ & \\
\hline$\$ 200 \mathrm{~K}$ & $\$ 766$ & $\$ 870$ & \\
\hline \multirow[t]{2}{*}{$\$ 335 \mathrm{~K}+$} & $\$ 693$ & $\$ 791$ & \\
\hline & & $\begin{array}{l}\text { Withdrawals Taxed at } \\
\text { Parents' Tax Rate }\end{array}$ & $\begin{array}{l}\text { Withdrawals Taxed at } \\
\text { Child's Tax Rate }\end{array}$ \\
\hline \multicolumn{4}{|c|}{529 (Deduction) } \\
\hline$\$ 35 \mathrm{~K}$ & $\$ 2,188$ & $\$ 1,825$ & $\$ 1,825$ \\
\hline$\$ 50 \mathrm{~K}$ & $\$ 1,976$ & $\$ 1,511$ & $\$ 1,637$ \\
\hline$\$ 100 \mathrm{~K}$ & $\$ 1,811$ & $\$ 1,143$ & $\$ 1,491$ \\
\hline$\$ 150 \mathrm{~K}$ & $\$ 1,683$ & $\$ 981$ & $\$ 1,378$ \\
\hline$\$ 200 \mathrm{~K}$ & $\$ 1,475$ & $\$ 734$ & $\$ 1,193$ \\
\hline$\$ 335 \mathrm{~K}+$ & $\$ 1,391$ & $\$ 638$ & $\$ 1,119$ \\
\hline \multicolumn{4}{|c|}{529 (No Deduction) } \\
\hline$\$ 35 \mathrm{~K}$ & $\$ 2,026$ & $\$ 1,682$ & $\$ 1,682$ \\
\hline$\$ 50 \mathrm{~K}$ & $\$ 1,808$ & $\$ 1,369$ & $\$ 1,488$ \\
\hline$\$ 100 \mathrm{~K}$ & $\$ 1,634$ & $\$ 1,008$ & $\$ 1,334$ \\
\hline$\$ 150 \mathrm{~K}$ & $\$ 1,511$ & $\$ 854$ & $\$ 1,225$ \\
\hline$\$ 200 \mathrm{~K}$ & $\$ 1,317$ & $\$ 623$ & $\$ 1,053$ \\
\hline$\$ 335 \mathrm{~K}+$ & $\$ 1,238$ & $\$ 533$ & $\$ 983$ \\
\hline
\end{tabular}

Note: In the case of college attendance, funds are drawn down starting in year 18 of the investment horizon. Otherwise, funds are withdrawn in year 22. 
Table 6

Aid System's Treatment of Saving Alternatives in Aid Determination

\begin{tabular}{|l|c|c|c|}
\hline \multicolumn{1}{|c|}{ Investment Option } & $\begin{array}{c}\text { Annual Assessment on } \\
\text { Asset Balance }\end{array}$ & $\begin{array}{c}\text { Annual Assessment on } \\
\text { Earnings Net of Income Tax }\end{array}$ & Assessment of Withdrawals \\
\hline Non-Advantaged Account, Parent & $5.64 \%$ & $47 \%$ of realized earnings net of income tax \\
\hline Traditional IRA & $0 \%$ & $0 \%$ & $47 \%$ of withdrawal net of income tax \\
\hline 529 & $5.64 \%$ & $0 \%$ & None \\
\hline Coverdell & $5.64 \%$ & $0 \%$ & None \\
\hline UTMA & $35 \%$ & $50 \%$ & $50 \%$ of realized earnings net of income tax \\
\hline
\end{tabular}

Note: In early 2004, the US Department of Education altered the treatment of the Coverdell in the determination of aid eligibility. This chart, and the paper's calculations, reflect this new treatment. 
Table 7

After-Tax Return to College Savings Alternatives, Net of Financial Aid Losses

\begin{tabular}{|c|c|c|c|c|}
\hline & $\begin{array}{l}\text { After-Tax } \\
\text { Return }\end{array}$ & $\begin{array}{l}\text { After-Tax Return, } \\
\text { Net of Aid Loss }\end{array}$ & $\begin{array}{l}\text { Aid Loss As \% of } \\
\text { Asset Balance at } \\
\text { Start of College }\end{array}$ & $\begin{array}{l}\text { Aid Loss As \% of } \\
\text { After-Tax Return }\end{array}$ \\
\hline \multicolumn{5}{|c|}{529 (Deduction) } \\
\hline$\$ 35 \mathrm{~K}$ & $\$ 2,188$ & $\$ 1,772$ & $15 \%$ & $19 \%$ \\
\hline$\$ 50 \mathrm{~K}$ & $\$ 1,976$ & $\$ 1,587$ & $15 \%$ & $20 \%$ \\
\hline$\$ 100 \mathrm{~K}$ & $\$ 1,811$ & $\$ 1,444$ & $15 \%$ & $20 \%$ \\
\hline$\$ 150 \mathrm{~K}$ & $\$ 1,683$ & $\$ 1,333$ & $15 \%$ & $21 \%$ \\
\hline$\$ 200 \mathrm{~K}$ & $\$ 1,475$ & - & - & - \\
\hline$\$ 335 \mathrm{~K}+$ & $\$ 1,391$ & - & - & - \\
\hline \multicolumn{5}{|c|}{529 (No Deduction) } \\
\hline$\$ 35 \mathrm{~K}$ & $\$ 2,026$ & $\$ 1,631$ & $15 \%$ & $19 \%$ \\
\hline$\$ 50 \mathrm{~K}$ & $\$ 1,808$ & $\$ 1,441$ & $15 \%$ & $20 \%$ \\
\hline$\$ 100 \mathrm{~K}$ & $\$ 1,634$ & $\$ 1,290$ & $15 \%$ & $21 \%$ \\
\hline$\$ 150 \mathrm{~K}$ & $\$ 1,511$ & $\$ 1,183$ & $15 \%$ & $22 \%$ \\
\hline$\$ 200 \mathrm{~K}$ & $\$ 1,317$ & - & - & - \\
\hline$\$ 335 \mathrm{~K}+$ & $\$ 1,238$ & - & - & - \\
\hline \multicolumn{5}{|l|}{ ESA } \\
\hline$\$ 35 \mathrm{~K}$ & $\$ 2,026$ & $\$ 1,631$ & $15 \%$ & $19 \%$ \\
\hline$\$ 50 \mathrm{~K}$ & $\$ 1,808$ & $\$ 1,441$ & $15 \%$ & $20 \%$ \\
\hline$\$ 100 \mathrm{~K}$ & $\$ 1,634$ & $\$ 1,290$ & $15 \%$ & $21 \%$ \\
\hline$\$ 150 \mathrm{~K}$ & $\$ 1,511$ & $\$ 1,183$ & $15 \%$ & $22 \%$ \\
\hline$\$ 200 \mathrm{~K}$ & $\$ 1,317$ & - & - & - \\
\hline$\$ 335 \mathrm{~K}+$ & $\$ 1,238$ & - & - & - \\
\hline \multicolumn{5}{|l|}{ UTMA } \\
\hline$\$ 35 \mathrm{~K}$ & $\$ 1,706$ & $-\$ 1,388$ & $124 \%$ & $181 \%$ \\
\hline$\$ 50 \mathrm{~K}$ & $\$ 1,511$ & $-\$ 1,360$ & $124 \%$ & $190 \%$ \\
\hline$\$ 100 \mathrm{~K}$ & $\$ 1,355$ & $-\$ 1,337$ & $124 \%$ & $199 \%$ \\
\hline$\$ 150 \mathrm{~K}$ & $\$ 1,245$ & $-\$ 1,219$ & $119 \%$ & $198 \%$ \\
\hline$\$ 200 \mathrm{~K}$ & $\$ 1,072$ & - & - & - \\
\hline$\$ 335 \mathrm{~K}+$ & $\$ 1,001$ & - & - & - \\
\hline \multicolumn{5}{|c|}{ Traditional IRA } \\
\hline$\$ 35 \mathrm{~K}$ & $\$ 2,026$ & $\$ 987$ & $33 \%$ & $51 \%$ \\
\hline$\$ 50 \mathrm{~K}$ & $\$ 1,808$ & $\$ 844$ & $31 \%$ & $53 \%$ \\
\hline$\$ 100 \mathrm{~K}$ & $\$ 1,634$ & $\$ 730$ & $27 \%$ & $55 \%$ \\
\hline$\$ 150 \mathrm{~K}$ & $\$ 1,511$ & $\$ 649$ & $26 \%$ & $57 \%$ \\
\hline$\$ 200 \mathrm{~K}$ & $\$ 1,317$ & - & - & - \\
\hline$\$ 335 \mathrm{~K}+$ & $\$ 1,238$ & - & - & - \\
\hline
\end{tabular}

Notes: Assumes portfolio mix of Table 2. One-time investment of $\$ 1,000$ at birth of child with all after-tax earnings reinvested. Funds drawn down over the final four years of the investment horizon. 
Figure 1: After-Tax Return to College Savings Options

nominal return to $\$ 1,000$ of pretax savings, household taxable income of $\$ 50,000$

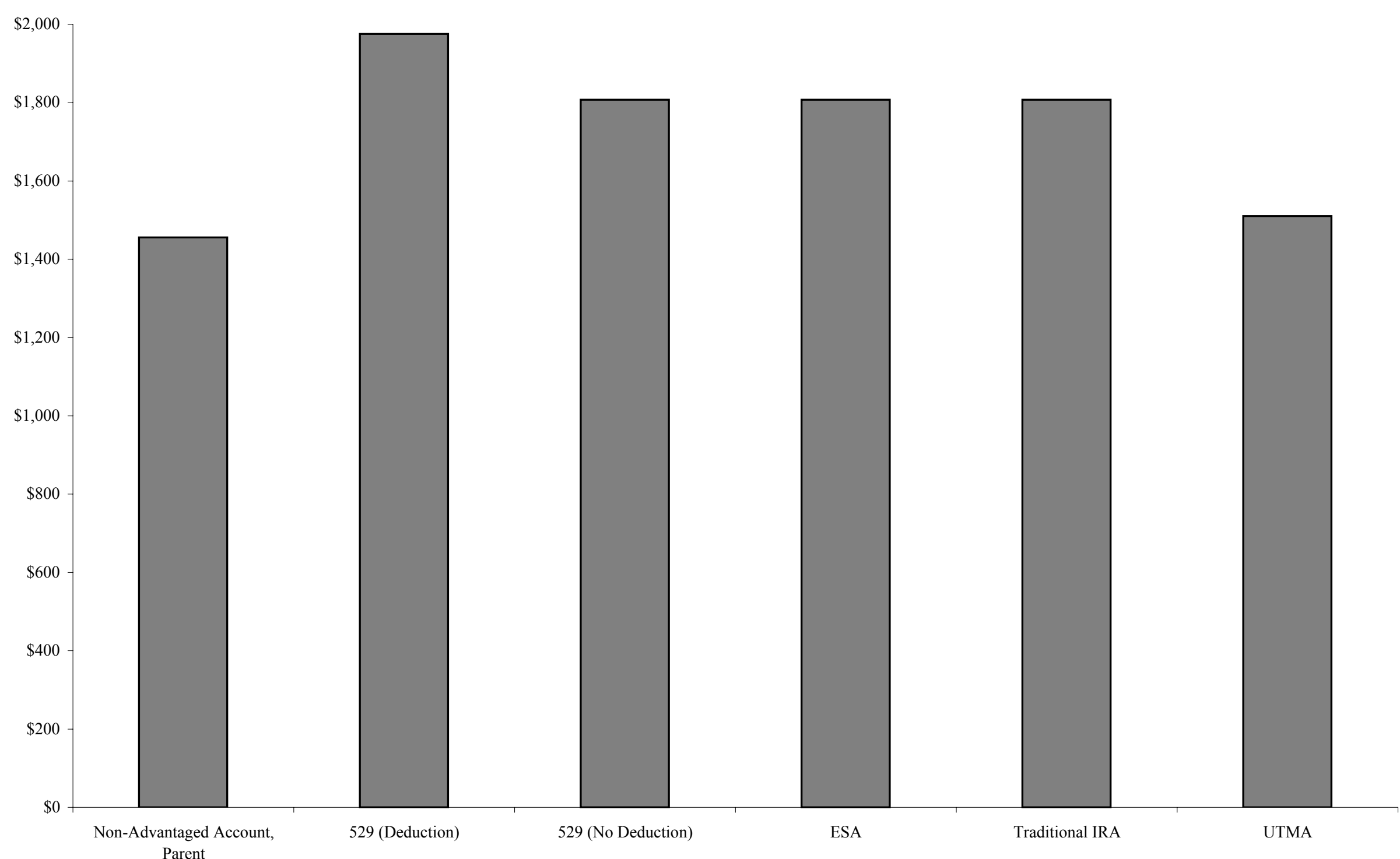

Notes: Assumes portfolio mix of Table 3. One-time investment of $\$ 1,000$ at birth of child with all after-tax earnings reinvested. Funds drawn down over the final four years of the investment horizon. 
Figure 2:

After-Tax Return to Non-Advantaged Account Held in Name of Parent

nominal return to $\$ 1,000$ of pretax savings

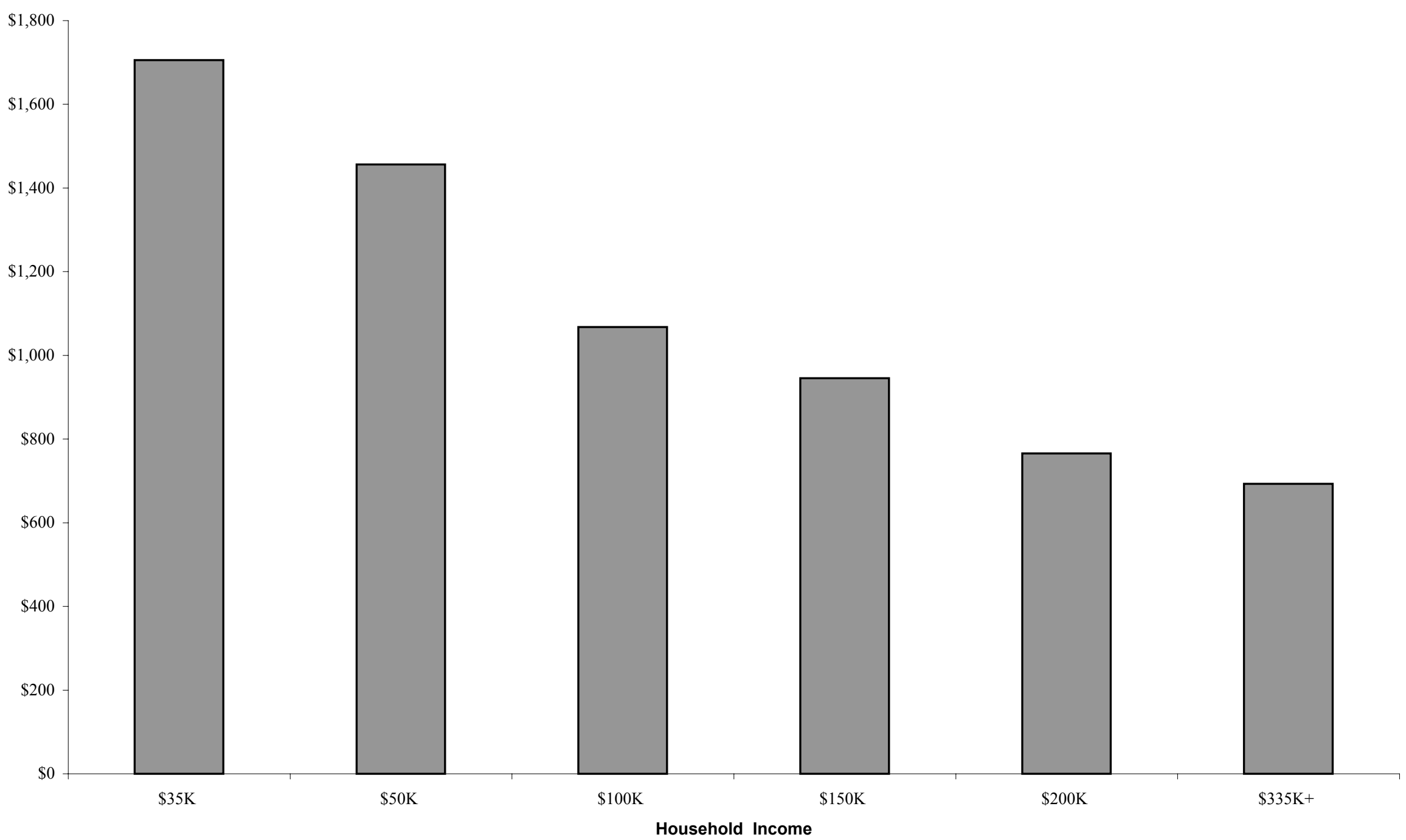

Notes: Assumes portfolio mix of Table 3. One-time investment of $\$ 1,000$ at birth of child with all after-tax earnings reinvested. Funds drawn down over the final four years of the investment horizon. 
Figure 3:

After-Tax Return to College Saving Options

Relative to After-Tax Return to Non-Advantaged Account

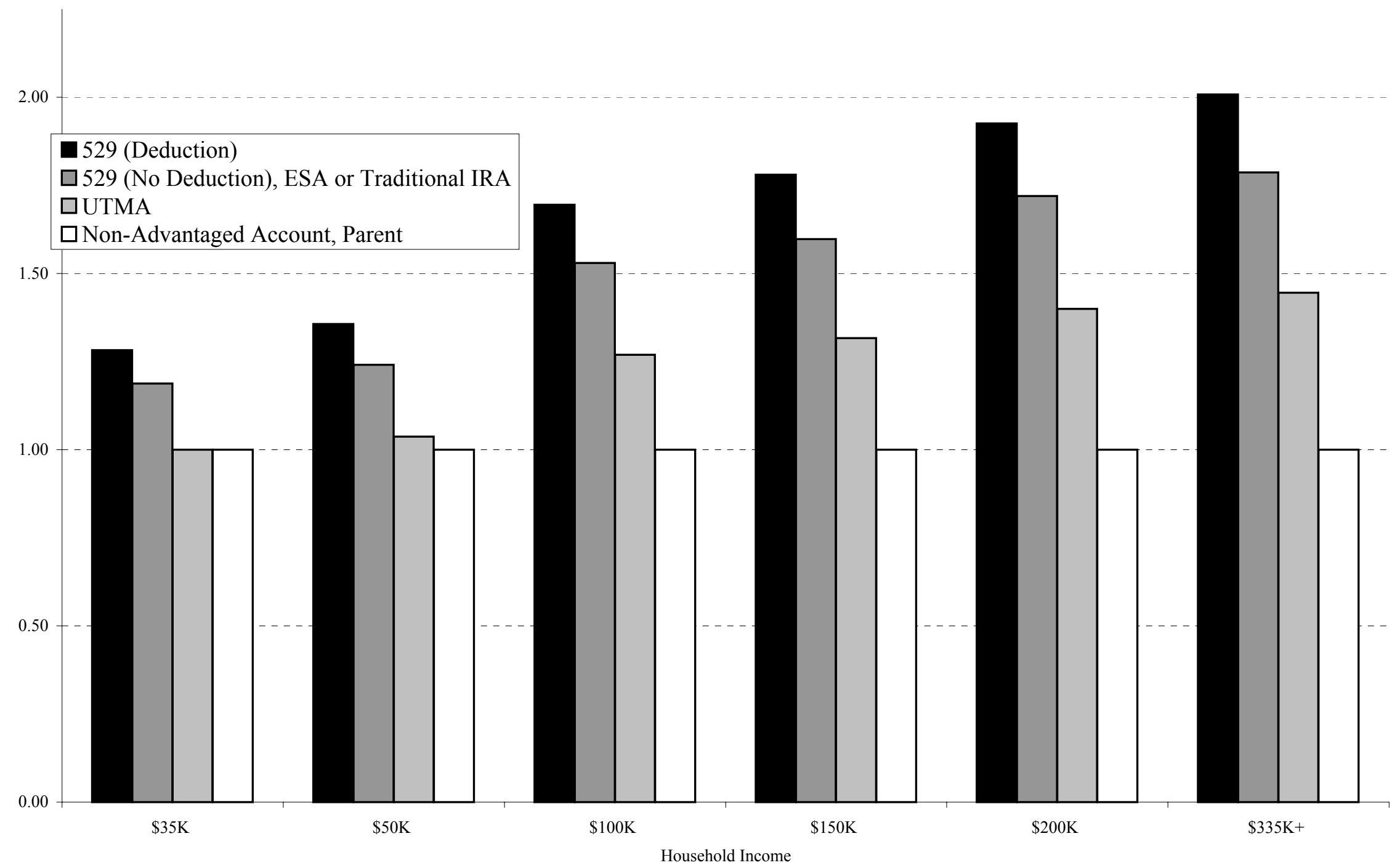

Notes: Assumes portfolio mix of Table 3. One-time investment of $\$ 1,000$ at birth of child with all after-tax earnings reinvested. Funds drawn down over the final four years of the investment horizon. 
Figure 4

After-Tax Return to College Saving Options

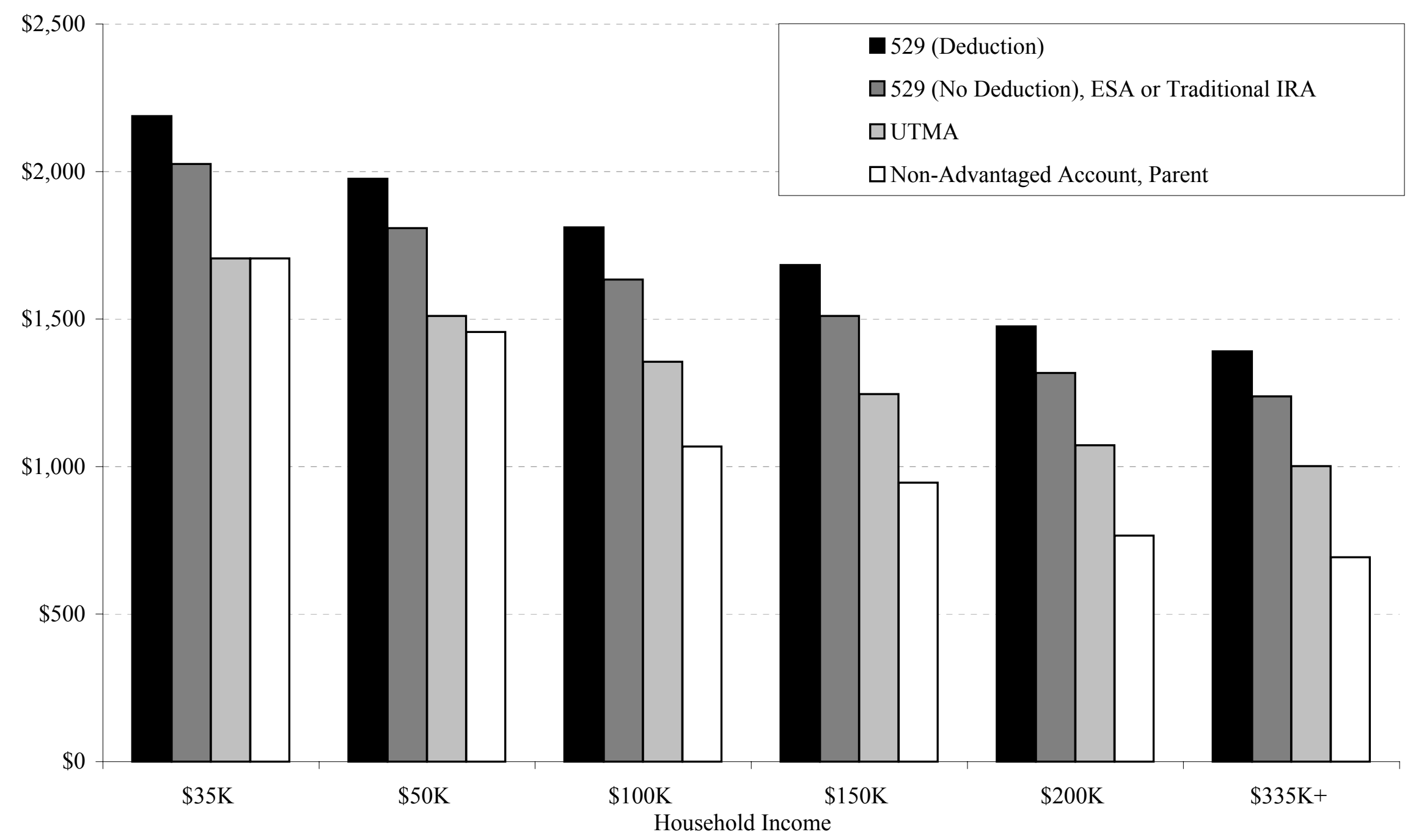

Notes: Assumes portfolio mix of Table 3. One-time investment of $\$ 1,000$ at birth of child with all after-tax earnings reinvested. Funds drawn down over the final four years of the investment horizon. 
Figure 5

After-Tax Returns, Non-College Use

Relative to After-Tax Return to Non-Advantaged Account

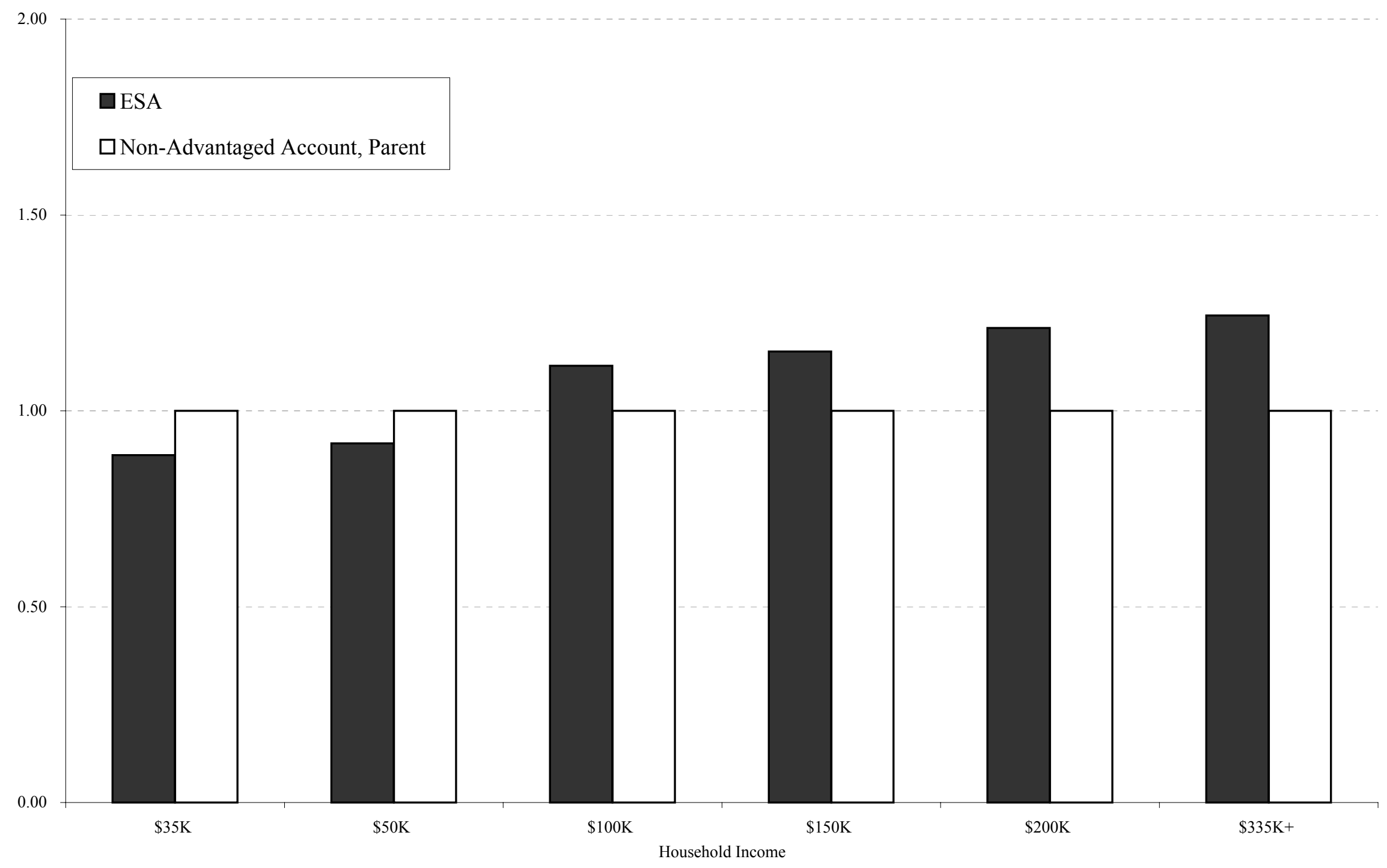

Notes: Assumes portfolio mix of Table 3. One-time investment of $\$ 1,000$ at birth of child with all after-tax earnings reinvested. Funds withdrawn in year 22 of the investment horizon. 
Figure 6

After-Tax Return to 529 (No Upfront Deduction), Non-College Use

Relative to After-Tax Return to Non-Advantaged Account

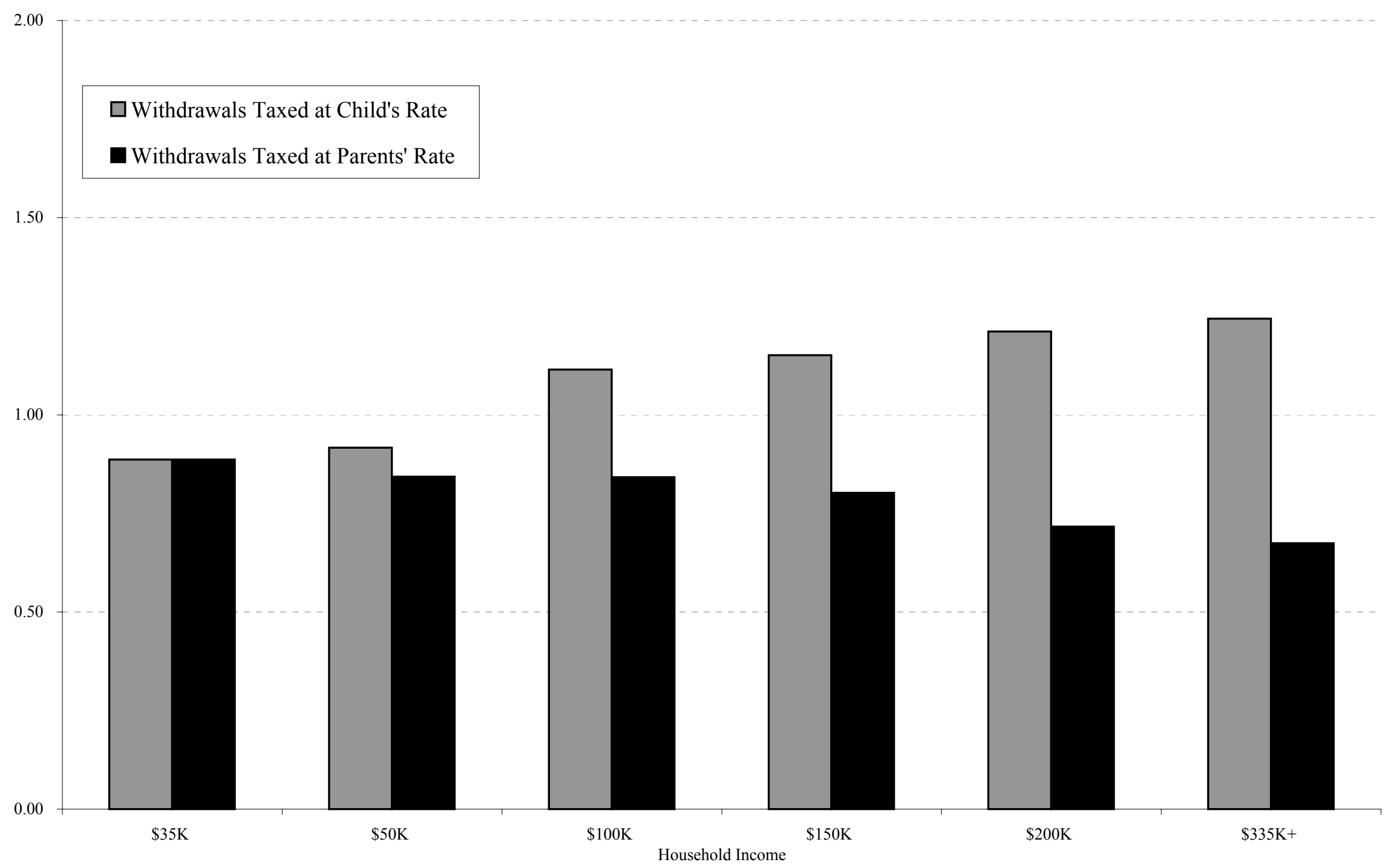

Notes: Assumes portfolio mix of Table 3. One-time investment of $\$ 1,000$ at birth of child with all after-tax earnings reinvested. Funds withdrawn in year 22 of the investment horizon. 
Figure 7

Return to College Saving Options, Net of Aid Lost and Income Tax

Assumes those in bottom four brackets are on aid margin; in top two brackets, assumed aid tax is zero

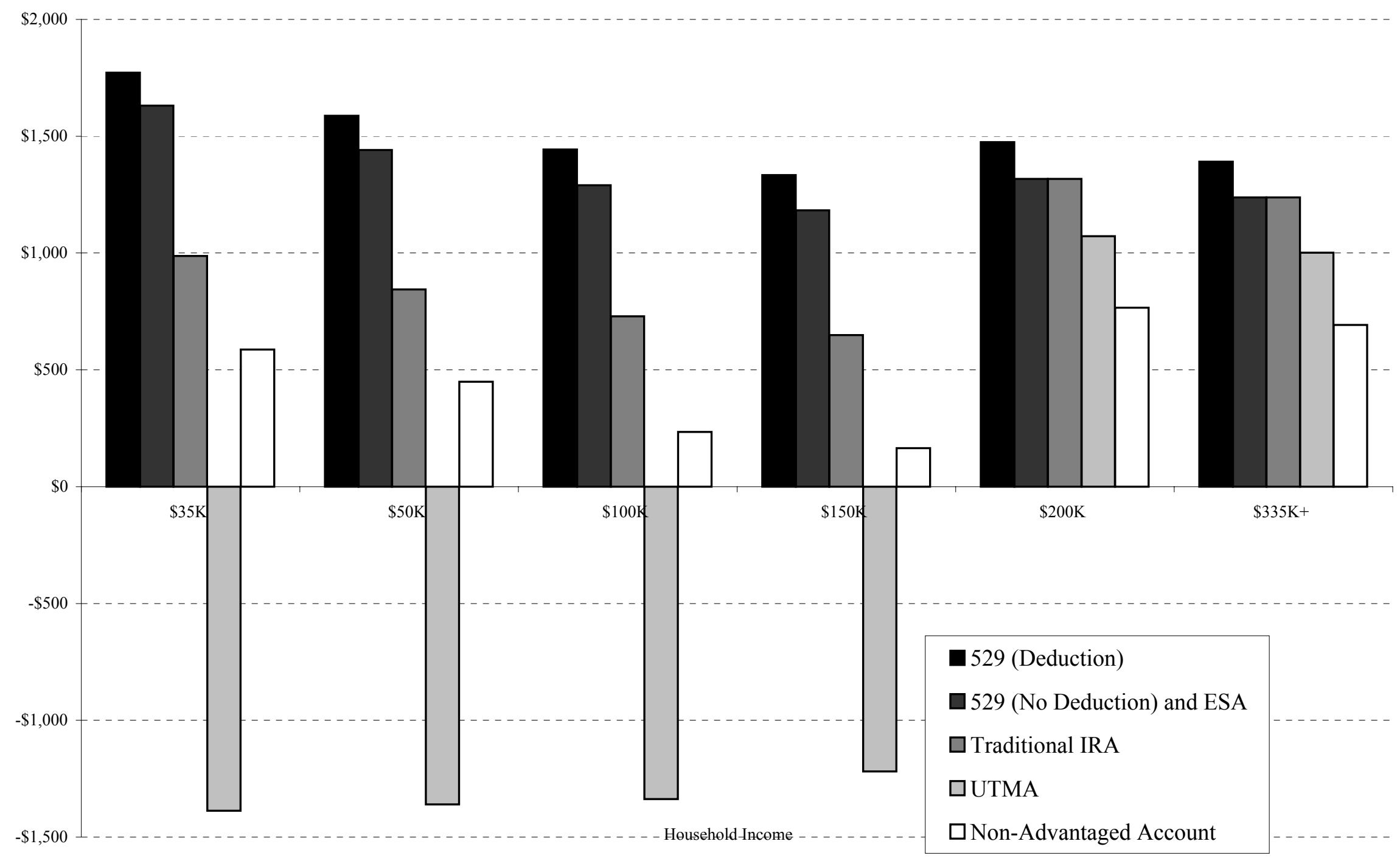

Notes: Assumes portfolio mix of Table 3. One-time investment of $\$ 1,000$ at birth of child with all after-tax earnings reinvested. Funds drawn down over the final four years of the investment horizon. 